The Free Internet Journal for Organic Chemistry
Review

Arkivoc 2020, i, 472-498

\title{
The synthesis of 1,2-azaphospholes, 1,2-azaphosphorines and 1,2-azaphosphepines
}

Noha M. Hassanin, ${ }^{a}$ Tarik E. Ali, ${ }^{b, a *}$ Mohammed A. Assiri, ${ }^{b}$ Hafez M. Elshaaer, ${ }^{a}$ and Somaia M. Abdel-Kariem ${ }^{a}$

${ }^{a}$ Department of Chemistry, Faculty of Education, Ain Shams University, Roxy, Cairo, Egypt

${ }^{b}$ Department of Chemistry, Faculty of Science, King Khalid University, Abha, Saudi Arabia

Email: tarik elsayed1975@yahoo.com, tismail@kku.edu.sa

Received 06-28-2020

Accepted $08-26-2020$

Published online $10-22-2020$

\section{Abstract}

1,2-Azaphospholes, 1,2-azaphosphorines and 1,2-azaphosphepines are prominent phosphorus heterocycles and are of interest due to their potent pharmacological activities. In this review, we provide the available literature data on the synthesis of 1,2-azaphospholes, 1,2-azaphosphorines and 1,2-azaphosphepines.

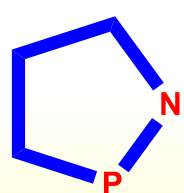

1,2-Azaphospholes

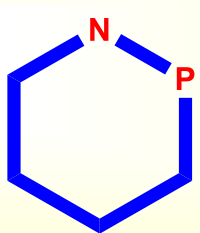

1,2-Azaphosphorines

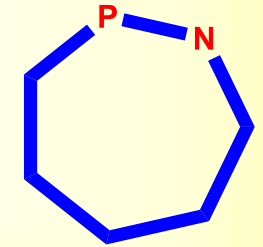

1,2-Azaphosphepines

Keywords: 1,2-azaphospholes, 1,2-azaphosphorines, 1,2-azaphosphepines, phosphorus heterocycles 


\section{Table of Contents}

1. Introduction

2. Synthetic Methods for Functionalized 1,2-Azaphosphole Derivatives

2.1 Cyclization of ethyl $\mathrm{N}$-methyl-3-bromopropylphosphonamidate with $\mathrm{NaH}$

2.2 Cyclization of $\gamma$-aminophosphorus compounds with bases

2.3 Reaction of methyleneaminophosphanes with activated alkenes and alkynes

2.4 Cyclization of 2-[2-(t-butylimino)cyclohexyl]acetonitrile with $\mathrm{PCl}_{3}$

2.5 Cyclization of 2-imino-2H-chromene-3-carboxamide with chlorodiphenylphosphine and diethyl phosphite

2.6 Cyclization of chromonyl arylidenes and hydrazones with phosphorus tribromide and diethyl phosphite

2.7 Reaction of dialkyl acetylenedicarboxylate with isocyanates and triphenylphosphine

2.8 Dearomatizing anionic cyclization of $N$-alkyl- $N$-benzyl-diarylphosphinamides

2.9 Rearrangement of 4,8-diaza-1-phosphaspiro[2.5] oct-1-ene with $\mathrm{GaCl}_{3}$

2.10 Thermal ring opening of $2 \mathrm{H}$-azaphosphirene complexes

2.11 Photolysis of azidophosphetanes

2.12 Reaction of adduct of phosphaalkynes and imidovanadium with acetylenes

2.13 Thermal decomposition of 7-phosphanorbornadiene complex

2.14 Reaction of I,3,2-diazaphosphole-4,5-dicarbonitriles with alkynes

2.15 Flash vacuum pyrolysis of 5-butyl-3-phenyl-1,2,3,4-triazaphosphole

2.16 Reaction of chlorophosphenium triflate with potassium metal

3. Synthetic Methods for Functionalized 1,2-Azaphosphorine Derivatives

3.1 Cyclization of phosphinamides using various bases

3.2 Cyclization of $\mathrm{N}$-[2-ethyl-3-methylhexa-1,3-dien-1-yl]butan-1-imine with $\mathrm{RPCl}_{2}$

3.3 Cyclization of 2-aminobiphenyl with $\mathrm{PCl}_{3}$

3.4 Cyclization of naphthylethylamine with thiophosphoryl chloride

3.5 Cyclization of 2-amino-3-ethynylnaphthalenes with triphenoxyphosphine

3.6 Cyclization of $2-(1 H$-indol-3-yl)- $N$-phenethylacetamides with phosphorus oxychloride

3.7 Reaction of a $1 \lambda^{5}, 3 \lambda^{5}$-diphosphete adduct with ethyl isothiocyanate

3.8 Ring expansion of 2,3-dihydro-1,2-azaphospholes by dichlorocarbene

3.9 Reaction of 1,3,2-diazaphosphinines with alkynes

4. Synthetic Methods for Functionalized 1,2-Azaphosphepine Derivatives

4.1 Ring expansion of phospholenes with benzonitrile

4.2 Ring expansion of 1,2-azaphosphinines with dichlorocarbene

5. Conclusions

Acknowledgements

References

\section{Introduction}

Organophosphorus compounds are important intermediates in organic synthesis and have been widely used as pharmaceutical, ${ }^{1-9}$ agricultural, ${ }^{10}$ and chemical agents. ${ }^{11-15}$ Recently, phosphorus heterocycles ${ }^{16,17}$ have 
received considerable interest because of their unique biological activities as antimicrobial ${ }^{18}$ and their $^{2}$ anticancer effects. ${ }^{19-22}$ Ifosfamide and cyclophosphamide are two important examples of phosphorus heterocycles that were launched on the market more than 30 years ago and are still used in treatment of cancer. ${ }^{23,24}$ Much attention has been directed to the synthesis of phosphorus heterocycles due to their wideranging utilities as synthetic intermediates in organic syntheses. ${ }^{25-31}$ Among these phosphorus heterocycles, 1,2-azaphospholes, 1,2-azaphosphorines and 1,2-azaphosphepines are of interest in several laboratories due to their potent pharmacological activities such as antitumor, ${ }^{32}$ complexing agents, ${ }^{33,34}$ and inhibitor of mammalian dihydroorotase. ${ }^{35}$ The present review is focused on the most methodologies for the construction of 1,2-azaphospholes, 1,2-azaphosphorines and 1,2-azaphosphepines up to the end of 2019 and to supplement the information available in literature. In addition, there is discussion of mechanisms.

\section{Synthetic Methods for Functionalized 1,2-Azaphosphole Derivatives}

\subsection{Cyclization of ethyl $\mathbf{N}$-methyl-3-bromopropylphosphonamidate with $\mathrm{NaH}$}

Cyclization of ethyl $\mathrm{N}$-methyl-3-bromopropylphosphonamidate (1) with sodium hydride in xylene at 120-125 ${ }^{\circ} \mathrm{C}$ gave 2-ethoxy-1-methyl-2-oxido-I,2-azaphospholidine (2) (Scheme 1). ${ }^{36}$

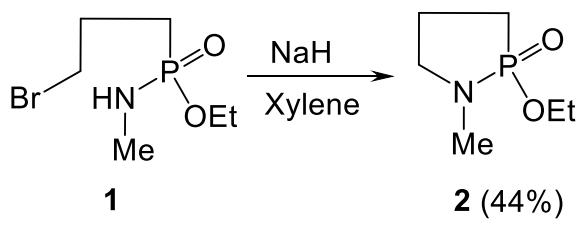

\section{Scheme 1}

\subsection{Cyclization of $\boldsymbol{\gamma}$-aminophosphorus compounds with bases}

Ring closure of $\mathrm{N}$-[3-(phenylphosphanyl)propyl]prop-2-en-1-amine (3) by using bromine in the presence of triethylamine or 1,2-diphenyldisulfane at 50-60 ${ }^{\circ} \mathrm{C}$ led to 1-allyl-2-phenyl-1,2-azaphospholidine (4) (Scheme 2). ${ }^{36}$

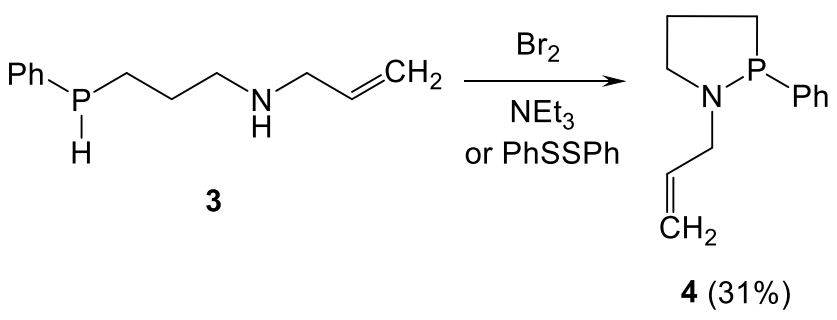

\section{Scheme 2}

Treatment of 2-amino-4-[hydroxy(methyl)phosphoryl]butanoic acid (5) with phosphorus pentachloride in the presence of triethylamine as a catalyst and ethanol at $45-50{ }^{\circ} \mathrm{C}$ furnished ethyl 2-amino-4-[ethoxy(methyl) phosphoryl] butanoate (6) and ethyl 2-methyl-2-oxido-1,2-azaphospholidine-5-carboxylate (7) (Scheme 3). The product 7 was also formed by treatment of acid $\mathbf{5}$ with thionyl chloride and a catalytic amount of DMF at 100$110{ }^{\circ} \mathrm{C}$, followed by addition of absolute ethanol. Enzyme catalyzed hydrolysis of product 7 to afford the corresponding free acid 8 (Scheme 3$).{ }^{37}$ 


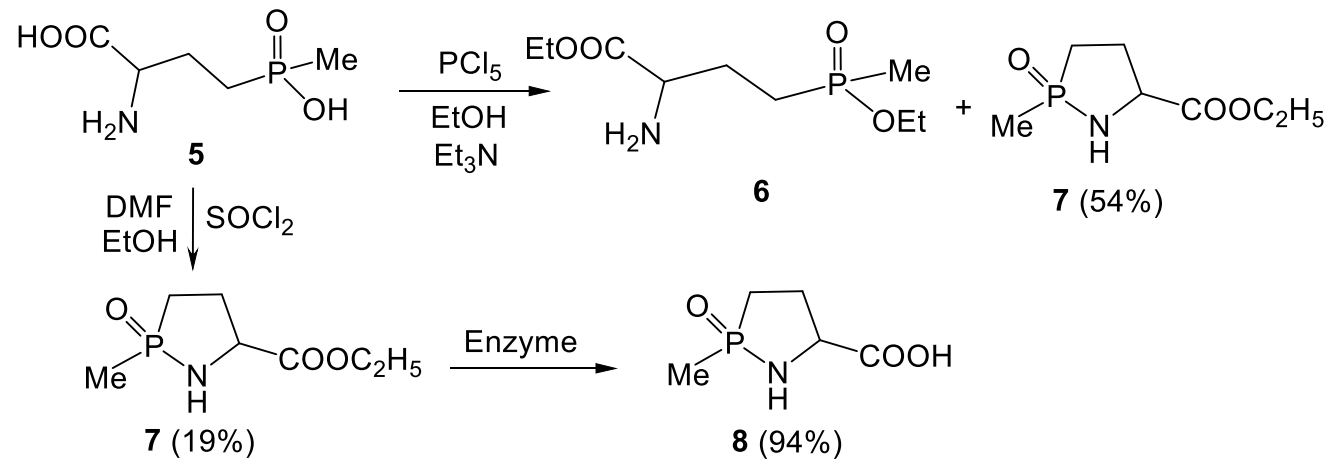

\section{Scheme 3}

\subsection{Reaction of methyleneaminophosphanes with activated alkenes and alkynes}

Methyleneaminophosphanes 9 reacted with activated alkenes such as acrylonitrile and methyl acrylate at room temperature to give the corresponding 5,5-diphenyl-4,5-dihydro-3H-1,2 $\lambda^{5}$-azaphospholes 10 (Scheme 4), while its reaction with dimethyl acetylenedicarboxylate furnished dimethyl 2,2-dimethyl-5,5-diphenyl-5 $\mathrm{H}$ 1,2 $2 \lambda^{5}$-azaphosphole-3,4-dicarboxylate (11) (Scheme 4). ${ }^{38}$

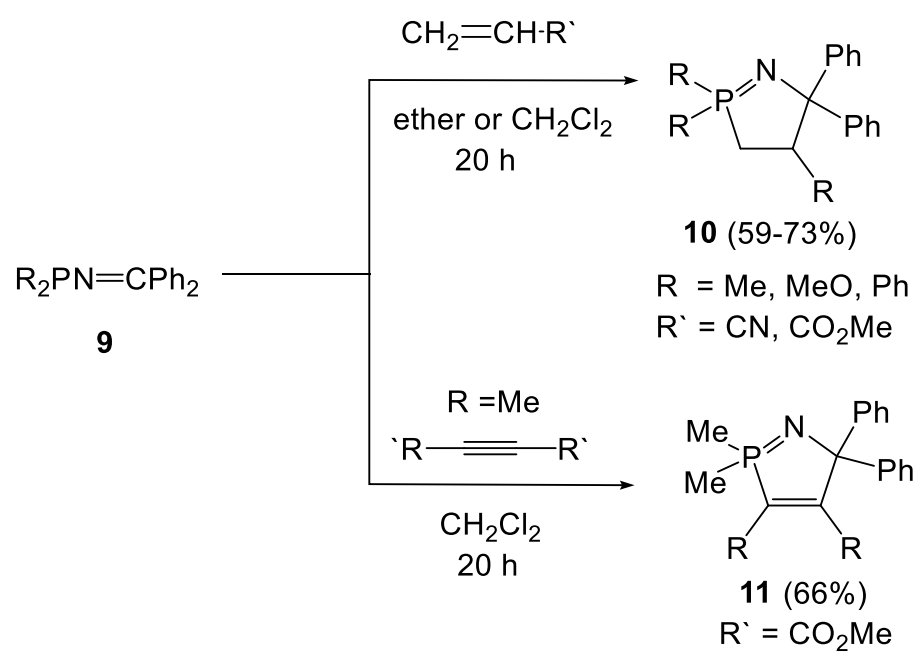

\section{Scheme 4}

\subsection{Cyclization of 2-[2-(t-butylimino)cyclohexyl]acetonitrile with $\mathrm{PCl}_{3}$}

1-t-Butyl-4,5,6,7-tetrahydro-1H-1,2-benzazaphosphole-3-carbonitrile (13) was prepared by condensation of 2-[2-(t-butylimino)cyclohexyl]acetonitrile (12) with $\mathrm{PCl}_{3}$ at $50-55{ }^{\circ} \mathrm{C}$ in the presence of triethylamine as a base. The yield was improved when 1,4-diazabicyclo[2.2.2] octane (DABCO) was used in place of triethylamine (Scheme 5). ${ }^{39}$

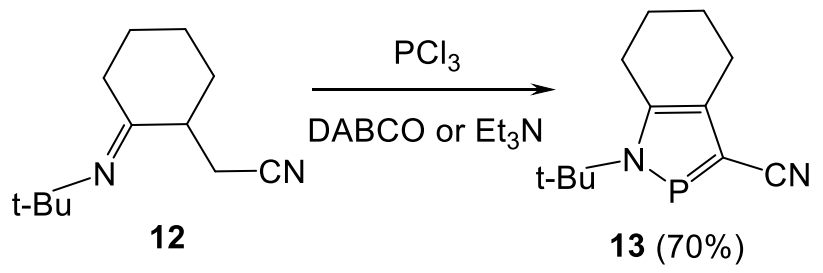

\section{Scheme 5}




\subsection{Cyclization of 2-imino-2H-chromene-3-carboxamide with chlorodiphenylphosphine and diethyl phosphite}

2-Imino-2H-chromene-3-carboxamide (14) reacted with chlorodiphenylphosphine in dry dioxane containing a few drops of triethylamine at $90-95{ }^{\circ} \mathrm{C}$ to yield 1,1-diphenyl-4-imino-3a,4-dihydro-15-chromeno[4,3-c][1,2] azaphosphol-3(2H)-one (15) (Scheme 6). ${ }^{40}$<smiles>CCN(CC)C(=O)c1cc2ccccc2oc1=N</smiles>

14<smiles></smiles>

$15(37 \%)$

\section{Scheme 6}

4-Amino-1-ethoxy-1-oxido-1,9b-dihydrochromeno[4,3-c][1,2]azaphosphole-3(2H)-one (16) was obtained by treatment of the carboxamide 14 with diethyl phosphite in the presence of $\mathrm{BF}_{3} . \mathrm{Et}_{2} \mathrm{O}$ as a catalyst at 80 $90{ }^{\circ} \mathrm{C}$ (Scheme 7). ${ }^{41}$<smiles>N=c1oc2ccccc2cc1C(N)=O</smiles>

14<smiles></smiles>

$16(40 \%)$

\section{Scheme 7}

\subsection{Cyclization of chromonyl arylidenes and hydrazones with phosphorus tribromide and diethyl phosphite}

2-Cyano-3-(4-oxo-4H-chromen-3-yl)prop-2-enamide (17) reacted with phosphorus tribromide in dry dioxane containing a catalytic quantity of triethylamine $90-95{ }^{\circ} \mathrm{C}$ to give two isomeric chromonyl-1,2-azaphospholes 18 and 19 (Scheme 8). ${ }^{42}$

Fusion of the chromonyl phenylhydrazone 20 with diethyl phosphite at $80-90{ }^{\circ} \mathrm{C}$ in the presence of $\mathrm{BF}_{3}$. Et $\mathrm{O}_{2} \mathrm{O}$ as a catalyst under Pudovik reaction conditions resulted in the nonisolable diethyl hydrazinophosphonate 21 (Scheme 9). The latter intermediate underwent spontaneous cyclization by elimination of ethanol to provide the chromeno[3,2- $d][1,2]$ azaphosphole 22 as two diastereoisomers (Scheme 9). ${ }^{32}$ 
<smiles>N#C/C(=C\c1coc2ccccc2c1=O)C(N)=O</smiles><smiles>O=C1C=C(c2coc3ccccc3c2=O)P(=O)(O)N1</smiles>

$18(29 \%)$

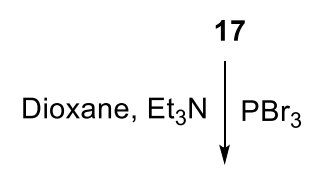

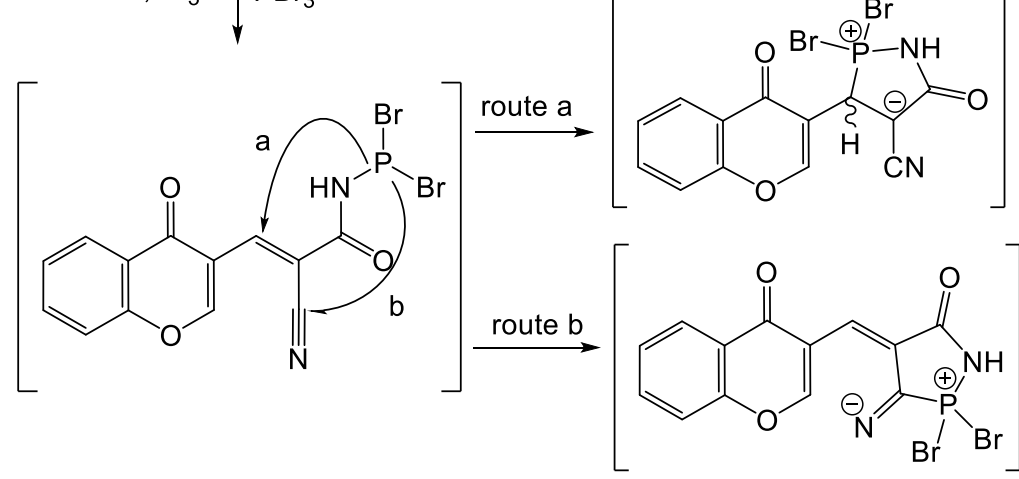<smiles>CC(C)CCO</smiles><smiles>N#CC1C(=O)NP(=O)(O)C1c1coc2ccccc2c1=O</smiles><smiles>N=C1C(=Cc2coc3ccccc3c2=O)C(=O)NP1(=O)O</smiles>
$19(25 \%)$

\section{Scheme 8}<smiles>Nc1oc2ccccc2c(=O)c1/C=N/Nc1ccccc1</smiles>

20

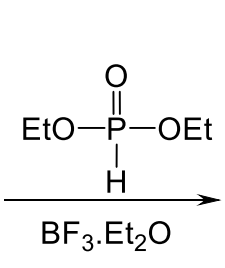

$80-90^{\circ} \mathrm{C}$<smiles>CCOP(=O)(OCC)C(C)(NNF)c1c(N)oc2ccccc2c1=O</smiles>

21<smiles>CCOP1(=O)Nc2oc3ccccc3c(=O)c2[C@H]1NNc1ccccc1</smiles>

22 (two diastereoisomers)

\section{Scheme 9}

\subsection{Reaction of dialkyl acetylenedicarboxylate with isocyanates and triphenylphosphine}

Dialkyl 2,5-dihydro-5-oxo-1,2-azaphosphole-3,4-dicarboxylates (25) resulted from a three-component reaction between triphenylphosphine, dialkyl acetylenedicarboxylate and arylsulfonyl isocyanates (Scheme 10). The product $\mathbf{2 5}$ was a result of the initial addition of triphenylphosphine to the acetylenic diester and subsequent attack of the resulting anion $\mathbf{2 3}$ to the carbonyl carbon atom of the arylsulfonyl isocyanate to yield the betaine 24. The latter betaine underwent spontaneous cyclization to produce the 1,2-azaphosphole 25 (Scheme 10). ${ }^{43}$ 


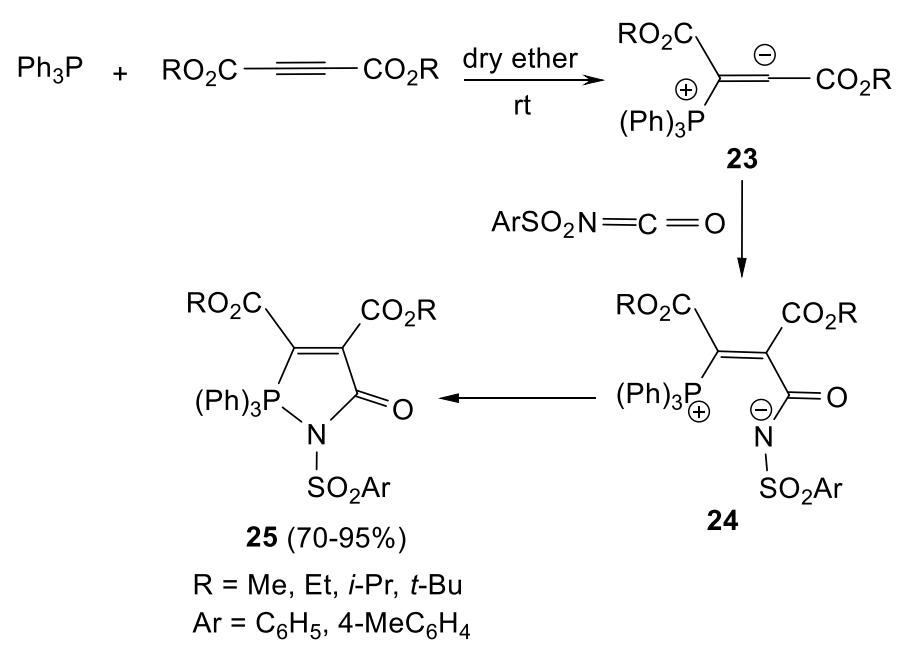

\section{Scheme 10}

\subsection{Dearomatizing anionic cyclization of $\mathbf{N}$-alkyl- $\mathbf{N}$-benzyl-diarylphosphinamides}

Treatment of $\mathrm{N}$-alkyl- $\mathrm{N}$-benzyl-diphenylphosphinamides (26) at low temperature with $\mathrm{n}$-BuLi in THF in the presence of HMPA or DMPU gave the anions $\mathbf{2 7}$. The developed anions $\mathbf{2 7}$ underwent anionic cyclization by Michael addition to the ortho position of the $P$-phenyl ring, which resulted in tetrahydro-2,1benzazaphospholes $\mathbf{2 8}$ as a dearomatized species trapped with methanol with high regio- and stereo-control (Scheme 11). ${ }^{44}$ Similarly, the cyclization of $N$-alkyl- $N$-benzyl-dinaphthylphosphinamides 29 by using $n$-BuLi in THF and subsequent trapping with a series of alkyl halides afforded a series of tetrahydro-1H-naphtho[1,2-c]$[1,2]$ azaphospholes 31-36 (Scheme 12). ${ }^{44}$

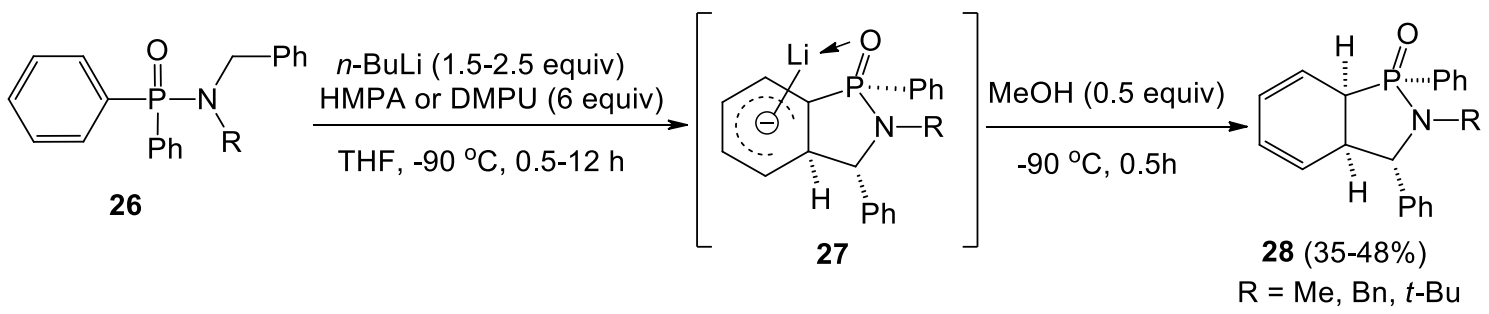

\section{Scheme 11}

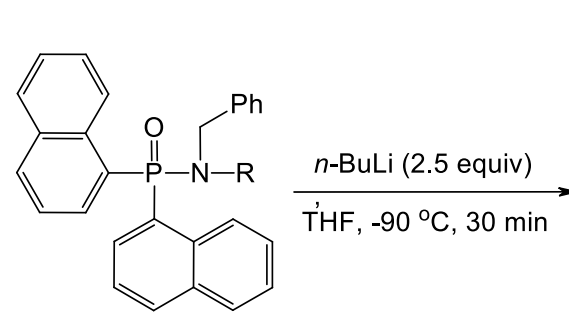

29

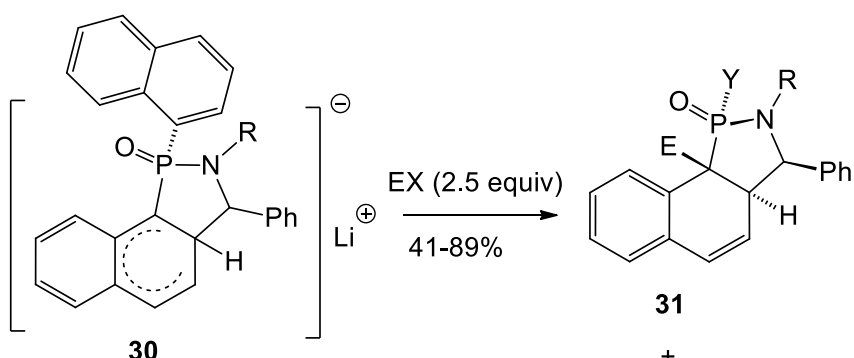

30<smiles>[Y][P@]1(=O)c2c(ccc3ccccc23)C(c2ccccc2)N1C</smiles>

36

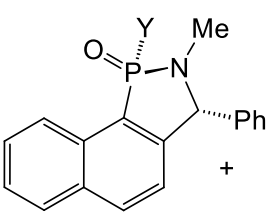

35

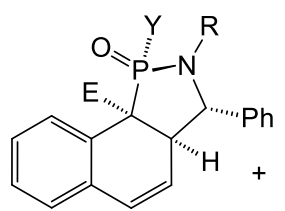

34

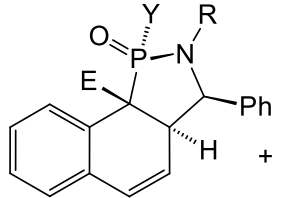

33

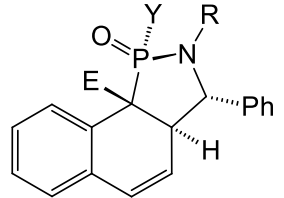

32

$E=H, M e, B n$, allyl $Y=1-n a p h t h y l, R=M e, B n$

\section{Scheme 12}


$N$-Benzyl- $N$-methyl-dinaphthylphosphinamide (29) underwent cyclization by using $\mathrm{n}$-BuLi in THF then adding acetic anhydride to isolate the azaphosphole $\mathbf{3 8}$ as the major product in the presence or absence of the co-solvent HMPA (Scheme 13). The acylation then deprotonation of the methyl group of the $\mathrm{CH}_{3} \mathrm{CO}$ moiety and trapping gave the product of $O$-acetylation $\mathbf{3 7}$, or $C$-acetylation 39 with low yields (Scheme 13). ${ }^{45}$

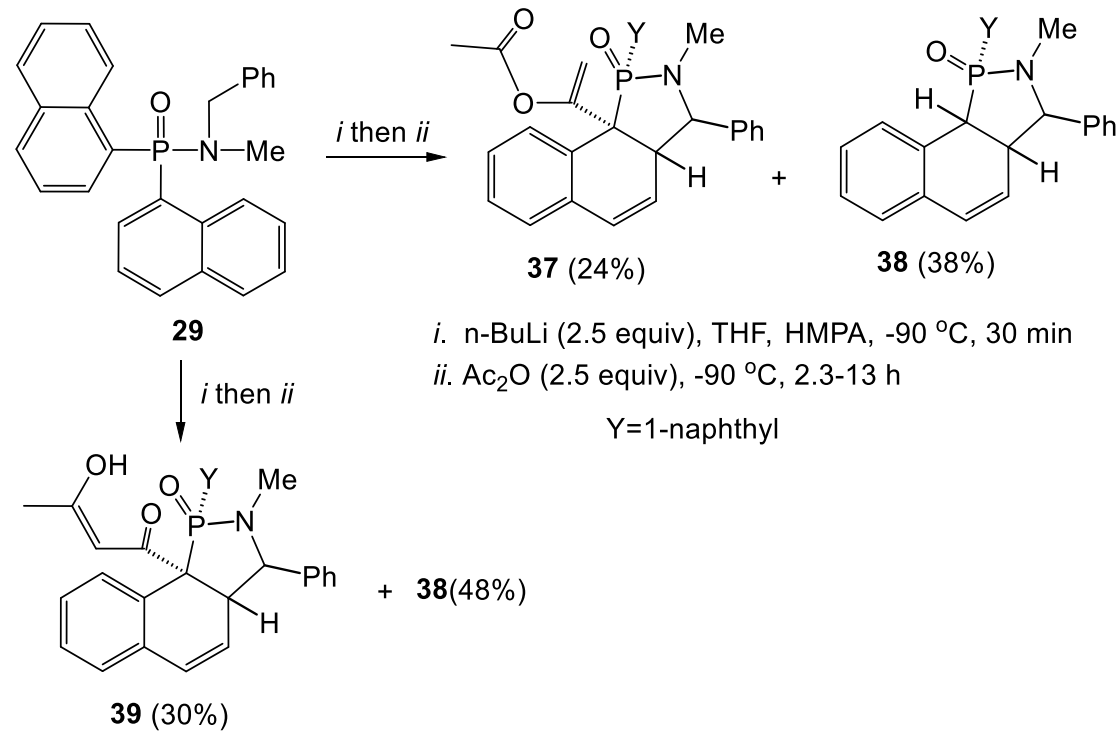

\section{Scheme 13}

In the same way, the reaction of compound $\mathbf{2 9}$ with n-BuLi in THF then acyclic $\alpha, \beta$-unsaturated aldehydes and ketones afforded the functionalized tricyclic 1,2-azaphospholes 40-44 (Scheme 14). ${ }^{45}$

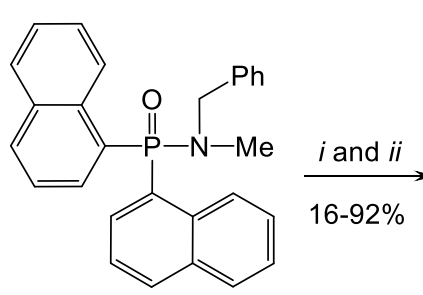

29

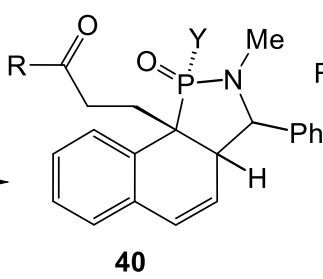

40

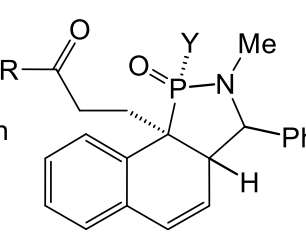

41<smiles>[3H]P1(=O)N(C)[C@H](c2ccccc2)[C@@H]2C=Cc3ccccc3C21CCC(C)=O</smiles>

42

$\mathrm{Y}=1$-naphthyl $\mathrm{R}=\mathrm{Me}, \mathrm{OMe}, \mathrm{Bu}$ i. BuLi (2.5 equiv), THF , $-90^{\circ} \mathrm{C}, 30 \mathrm{~min}$. ii. $\mathrm{CH}_{2}=\mathrm{CHCOR}$ (2.5 equiv), $-90^{\circ} \mathrm{C}, 0.3-13.5 \mathrm{~h}$.

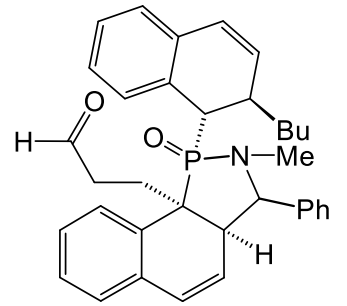

44

\section{Scheme 14}

The reaction of starting material $\mathbf{2 9}$ with $n$-BuLi in THF followed by addition of 2-cyclopenten-1-one or 2-cyclohexen-1-one took place with good yield and low selectivity to form a mixture of tricyclic 1,2-azaphospholes 45 and 46 with a cis-junction in a ratio of 1:1.6 (Scheme 15). Other products (47 and 48 ) were also formed due to the dearomatization of the two naphthalene rings (Scheme 15). ${ }^{45}$ 


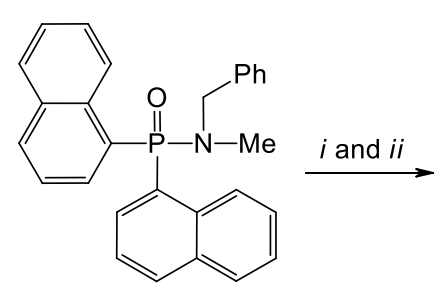

29

$\mathrm{Y}=1$-naphthyl

i. BuLi (2.5 equiv), THF , $-90^{\circ} \mathrm{C}, 30 \mathrm{~min}$.

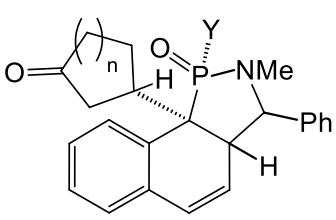

$45 n=1,2(27-50 \%)$

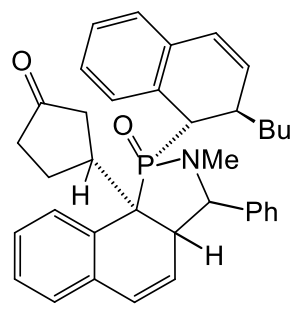

$47(10 \%)$

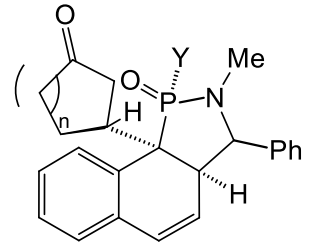

46, $n=1,2(22-43 \%)$

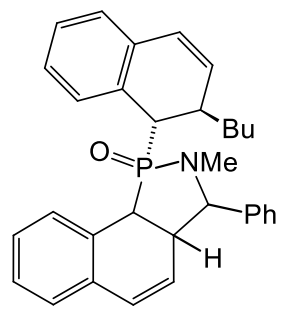

$48(5 \%)$

\section{Scheme 15}

\subsection{Rearrangement of 4,8-diaza-1-phosphaspiro[2.5] oct-1-ene with $\mathrm{GaCl}_{3}$}

Reaction of 2-t-butyl-6,6-dimethyl-4,8-bis(methylthio)-4,8-diaza-1-phosphaspiro[2.5]oct-1-ene-5,7-dione (49) with $\mathrm{GaCl}_{3}$ induced an unexpected rearrangement leading to the formation of the complex $\mathbf{5 0}$ which stabilized into 1,2-azaphosphole form 51 (Scheme 16). ${ }^{46}$

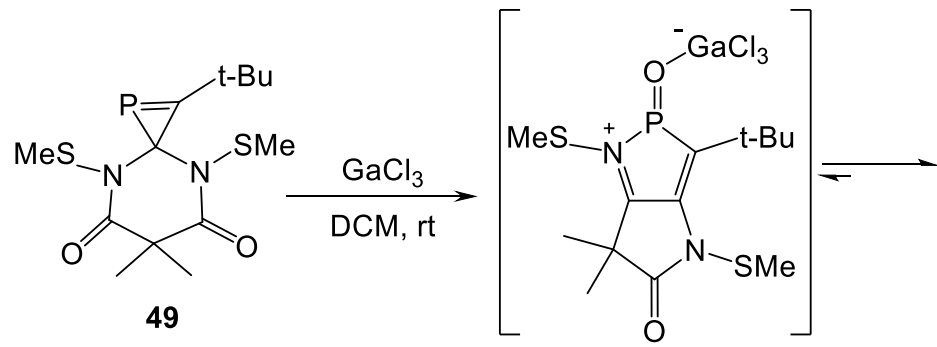

50<smiles>CC(C)(C)Op1c(C(C)(C)C)c2c([n+]1S(C)(C)C)N(S(C)(=O)=O)C(=O)C2(C)C</smiles>

$51(74 \%)$

\section{Scheme 16}

\subsection{Thermal ring opening of $\mathbf{2 H}$-azaphosphirene complexes}

The thermolysis of the (2H-azaphosphirene)tungsten carbonyl complex 52 at $60{ }^{\circ} \mathrm{C}$ gave the nitrilium phosphanylide complex 54, which reacted with acetylene to yield the 1,2-azaphosphole complex $\mathbf{5 5}$ (Scheme 17). ${ }^{47}$

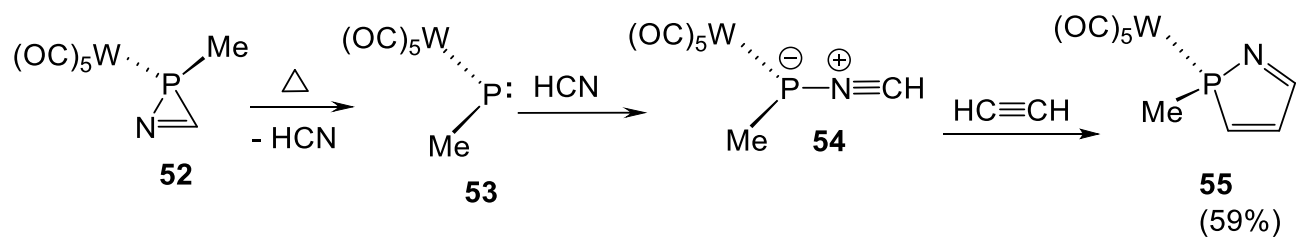

\section{Scheme 17}

Thermal ring opening of the (2H-1,2-azaphosphirene)tungsten complex 56 with dimethyl acetylenedicarboxylate and nitriles yielded the corresponding 1,2-azaphosphole complexes 57 (Scheme 18). When 1-piperidinocarbonitrile or dimethyl cyanamide was used, 1,3,2-oxazaphospholene complexes 58 (meso and 
racemic in ratio of 1:1) was also obtained beside the desired product 57 (Scheme 18). Furthermore, the reaction of complex $\mathbf{5 6}$ with 2-(triphenyl- $\lambda^{5}$-phosphanyl)acetonitrile led to the formation of 1,2-azaphosphole 59 (Scheme 18). ${ }^{33,48-50}$

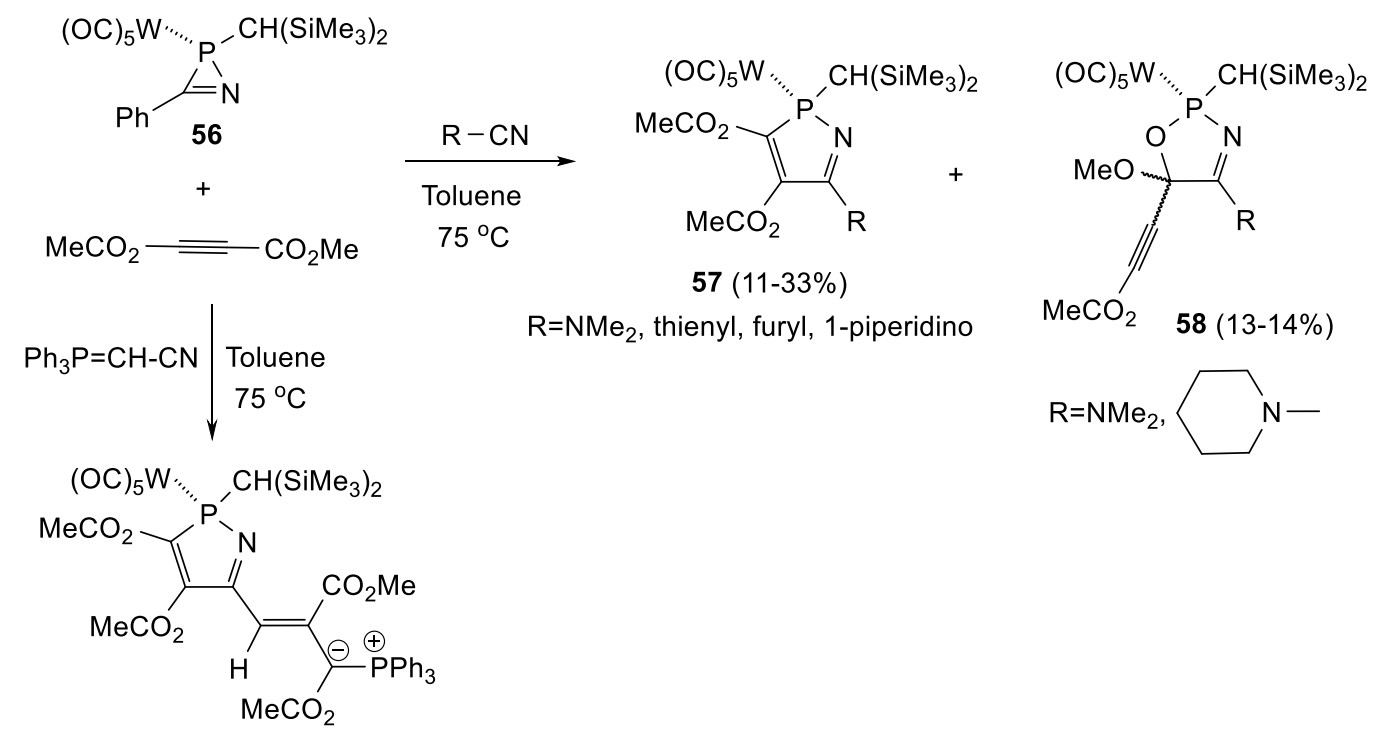

$59(41 \%)$

\section{Scheme 18}

Also, ring opening reaction of 1,2-azaphosphirene complex 56 with dimethyl acetylenedicarboxylate and benzonitrile in toluene furnished a mixture of $2 H$-1,2-azaphosphole complexes 60 and 61 (Scheme 19). The yield of complex 60 was significantly improved to $90 \%$ when the reaction was carried out photochemically in pentane at $-50{ }^{\circ} \mathrm{C}$. Heating of complex 60 in benzonitrile with sulfur gave the 2-sulfido-2H-1,2-azaphosphole 63 (Scheme 19). ${ }^{33,51-53}$

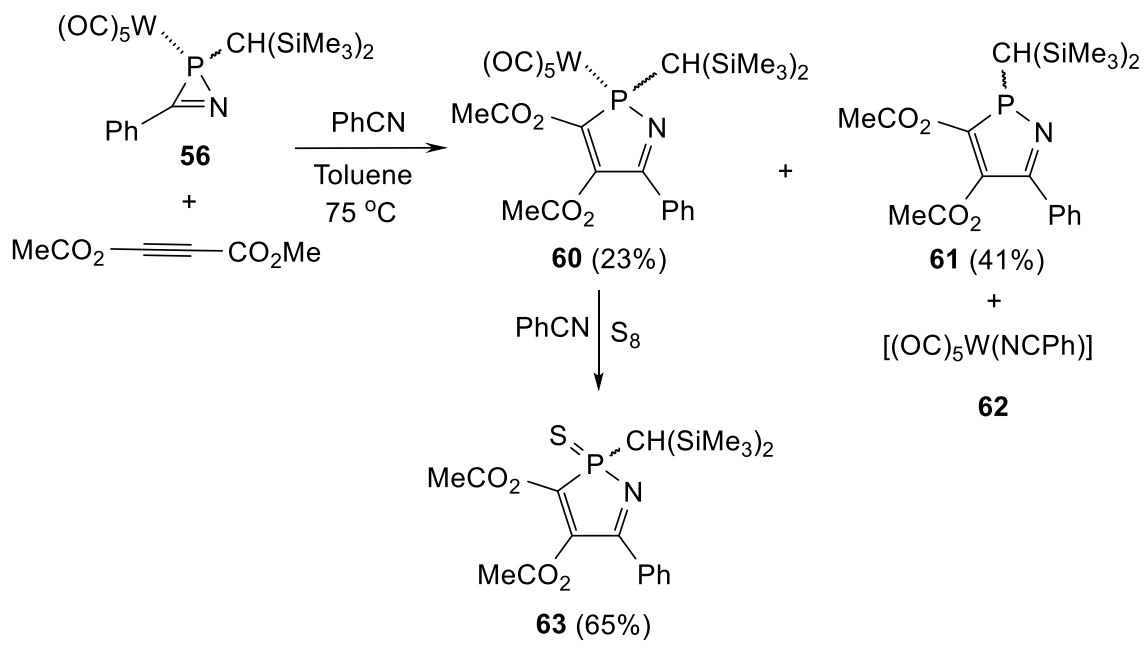

\section{Scheme 19}

On the other hand, the three component reactions of $2 \mathrm{H}$-azaphosphirene complex 56, ethyl propiolate and nitriles led to the formation of the regioisomeric $2 \mathrm{H}$-1,2-azaphosphole complexes 64 and 65 (Scheme 20). In case of using $\mathrm{Ph}_{3} \mathrm{P}=\mathrm{CH}(\mathrm{CN})(66)$, a mixture of 1,2-azaphosphole complexes 64 and 67 were formed. Also, 
reaction of complex 56 with ethyl propiolate and different nitriles in pentane gave 1,2-azaphospholes 65 in high yield (Scheme 20). ${ }^{49,50,52,54}$

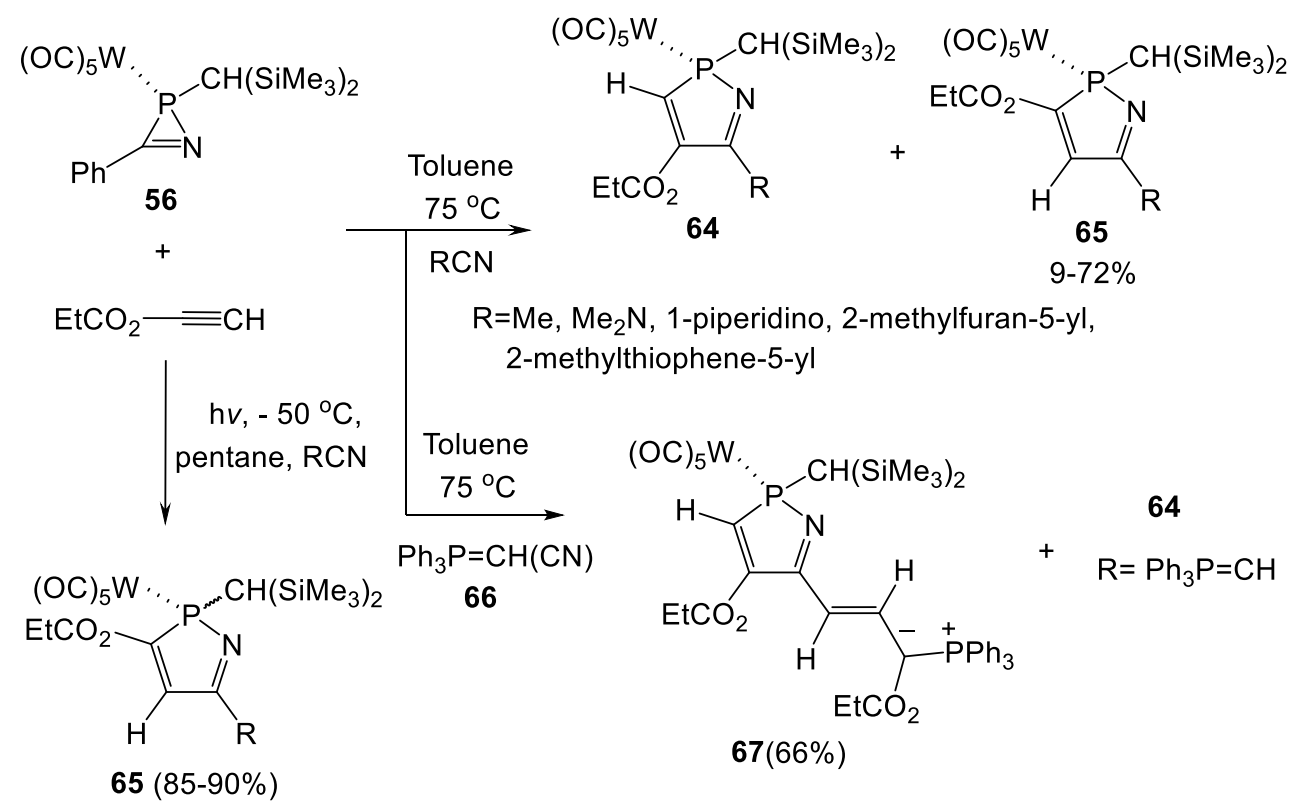

\section{Scheme 20}

Similarly, the ring-opening of the 1,2-azaphosphirene complex 68 in benzonitrile in the presence of dimethyl acetylenedicarboxylate as a trapping reagent afforded the 1,2-azaphosphole complex 69 . When the reaction was performed with $\mathrm{Ph}_{3} \mathrm{P}=\mathrm{NCN}$ in dry toluene, the 1,2-azaphosphole complex 70 was formed in high yield (Scheme 21). ${ }^{33,55}$
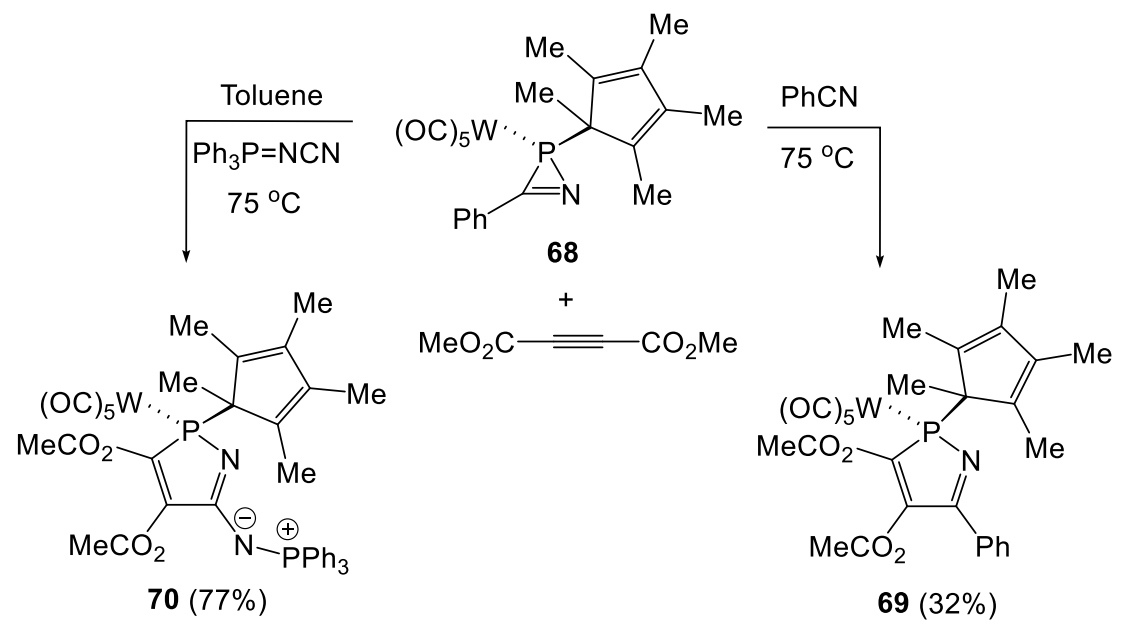

Scheme 21

Reaction of the (2H-azaphosphirene)tungsten complex $\mathbf{7 1}$ with trifluoromethanesulfonic acid, phenylacetylene and triethylamine in $\mathrm{CH}_{2} \mathrm{Cl}_{2}$ proceeded through $\mathrm{P}-\mathrm{C}$ bond ring enlargement to afford $2 \mathrm{H}-1,2-$ azaphosphole complex 72 in low yield (Scheme 22). ${ }^{56}$ 


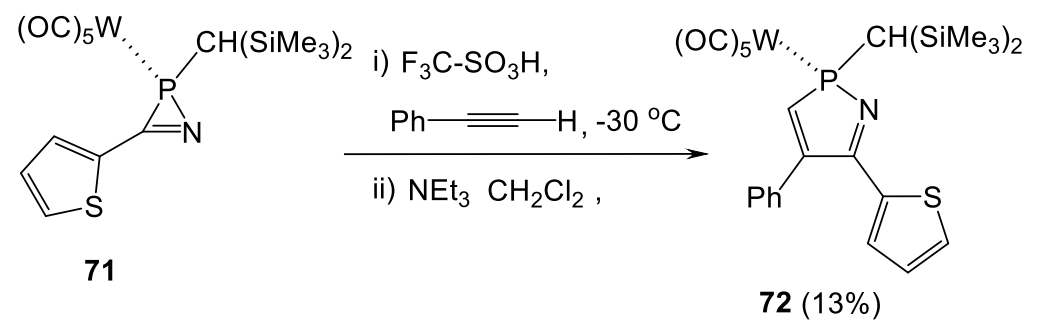

\section{Scheme 22}

\subsection{Photolysis of azidophosphetanes}

Photolysis of 1-azido-2,2,4,4-tetramethylphosphetane 1-oxide $73(\mathrm{R}=\mathrm{H})$ afforded the cyclic 1,2-azaphospholidine 75 by elimination of $\mathrm{N}_{2}$ and addition of methanol (Scheme 23). Likewise, photolysis of azide 73 $(\mathrm{R}=\mathrm{Me})$ gave a mixture of cis- and trans-1,2-azaphospholidines 76 (Scheme 23). ${ }^{57}$

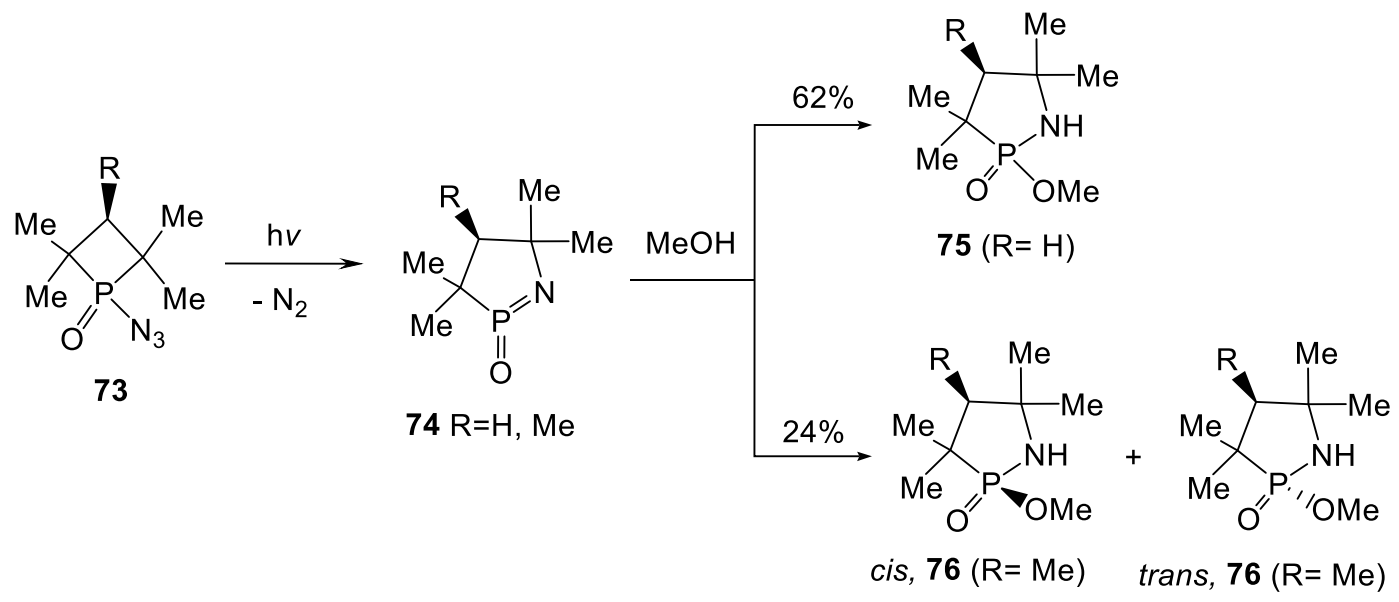

\section{Scheme 23}

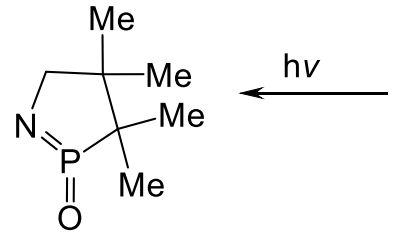

80<smiles>CO</smiles><smiles>COP1(=O)NCC(C)(C)C1(C)C</smiles>

81<smiles>CCCCCCP1(=O)CC(C)(C)C1(C)C</smiles>

77

78<smiles>CCCCCOC</smiles><smiles>COP1(=O)CC(C)(C)C(C)(C)N1</smiles>

79

\section{Scheme 24}


Unlike 73, the azide $\mathbf{7 7}$ lacks symmetry and has two possible modes of ring expansion. Thus, its photolysis in methanol yielded an approximately equimolar mixture (40\% total) of the isomeric 1,2-azaphospholidines 79 and $\mathbf{8 1}$ (Scheme 24). ${ }^{57}$

\subsection{Reaction of adduct of phosphaalkynes and imidovanadium with acetylenes}

The cycloadduct 84 was generated in situ by addition of an equimolar amount of a phosphaalkynes 83 to the imidovanadium complexes $\mathbf{8 2}$ (Scheme 25). The cycloadduct $\mathbf{8 4}$ was treated with an excess of disubstituted acetylenes in toluene at $-78{ }^{\circ} \mathrm{C}$ to form the tetrasubstituted 1,2-azaphospholes 85 in $31-71 \%$ yields (Scheme 25). ${ }^{58}$
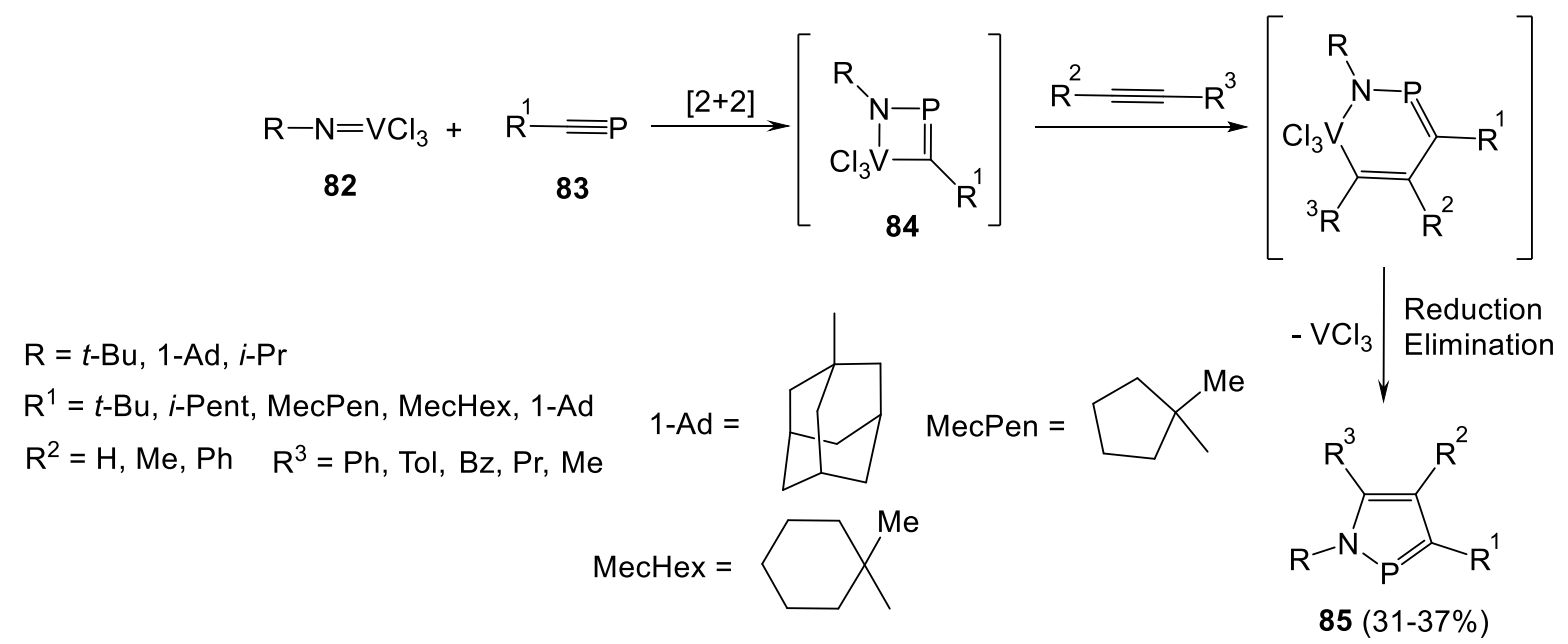

\section{Scheme 25}

\subsection{Thermal decomposition of 7-phosphanorbornadiene complex}

In the presence of piperidine-1-carbonitrile and dimethyl acetylenedicarboxylate, 7-phosphanorbornadiene complex 86 underwent thermal decomposition in xylene at $120^{\circ} \mathrm{C}$ to afford the 1,2 -azaphosphole complex 87
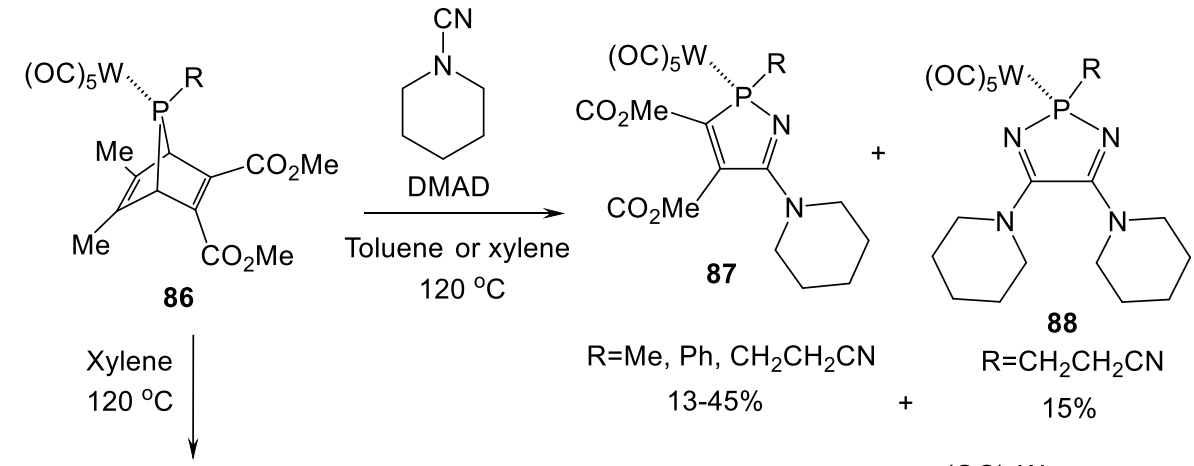

88

$$
\mathrm{R}=\mathrm{CH}_{2} \mathrm{CH}_{2} \mathrm{CN}
$$

$15 \%$
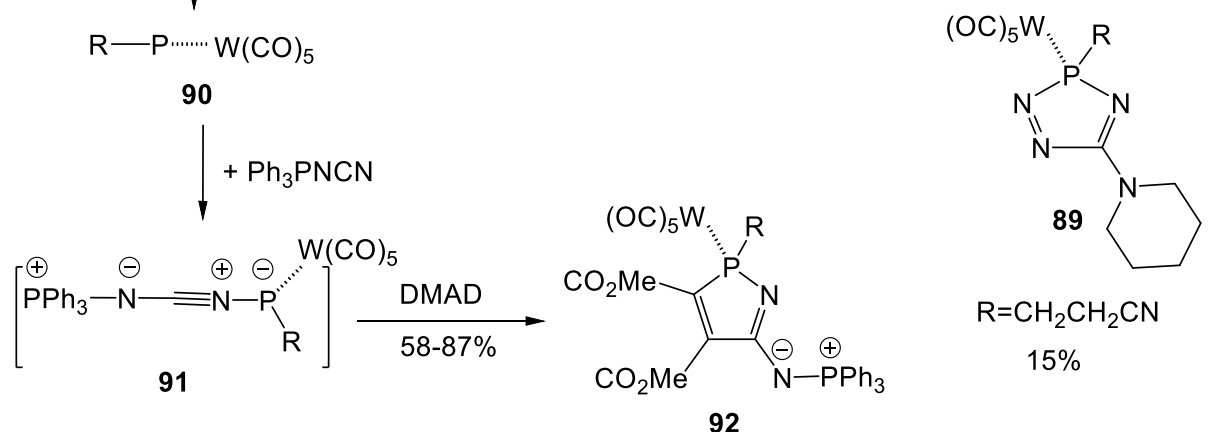
beside a complicated mixture of the regioisomeric complexes $\mathbf{8 8}$ and $\mathbf{8 9}$ (Scheme 26). When the reaction was performed in dry toluene, the product $2 \mathrm{H}$-1,2-azaphosphole complex 87 only was isolated. When another carbonitrile derivative such as $\mathrm{Ph}_{3} \mathrm{P}=\mathrm{NCN}$ was used, the thermal decomposition of complex 86 in $x y$ lene furnished the $2 \mathrm{H}$-1,2-azaphosphole complex 92 through [3+2] cycloaddition reaction of nitrilium phosphane ylide complexes 91 formed with dimethyl acetylenedicarboxylate (Scheme 26). ${ }^{59-61}$

\subsection{Reaction of I,3,2-diazaphosphole-4,5-dicarbonitriles with alkynes}

The regioselective cyclization of 1,3,2-diazaphosphole-4,5-dicarbonitriles 93 with symmetrical and non-symmetrical alkynes in chloroform at room temperature yielded the 1,2-azaphosphole-5-carbonitriles $\mathbf{9 4}$ (Scheme 27). In some cases of non-symmetrical alkynes, the other isomers 95 were also formed (Scheme 27). ${ }^{62}$

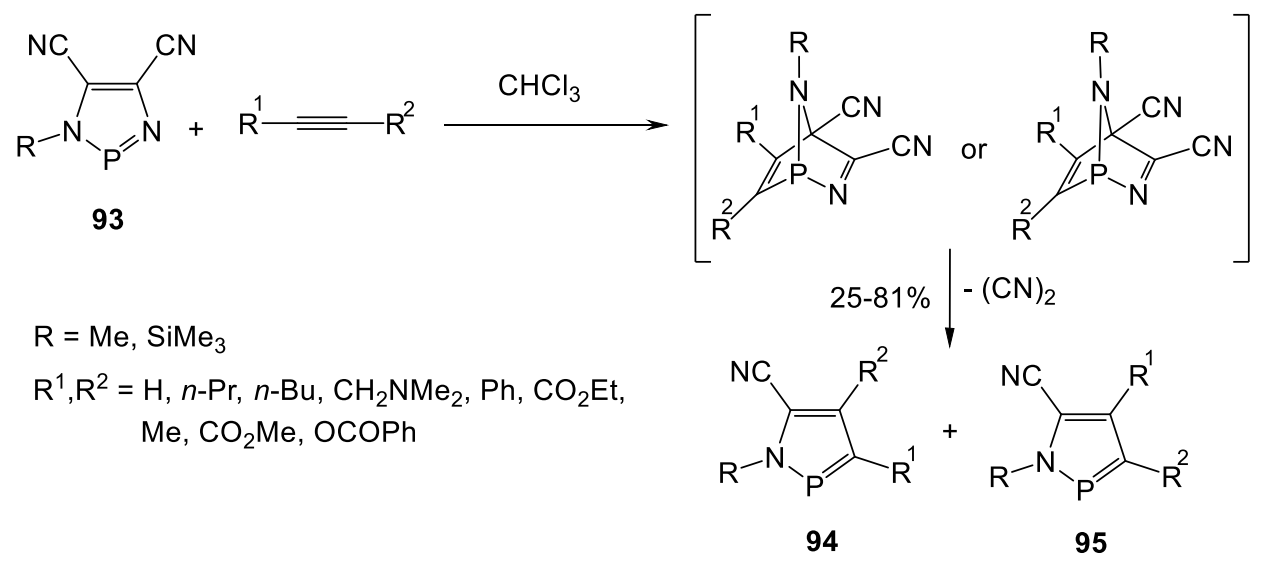

\section{Scheme 27}

\subsection{Flash vacuum pyrolysis of 5-butyl-3-phenyl-1,2,3,4-triazaphosphole}

Dinitrogen was split off from 5-butyl-3-phenyl-1,2,3,4-triazaphosphole (96) on flash vacuum pyrolysis to give the azaphosphirene intermediate 97 . This intermediate underwent 1,5-electrocyclization followed by proton migration to form the annulated 3-butyl-1H-[1,2]benzazaphosphole (98) and 2-butyl-1H-[1,3]benzazaphosphole (99) in a ratio of $4: 1$ (Scheme 28$)^{39}$

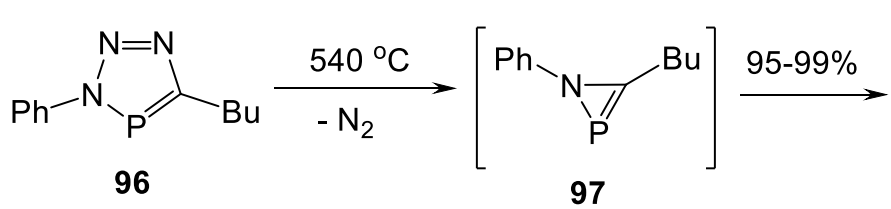

96
97

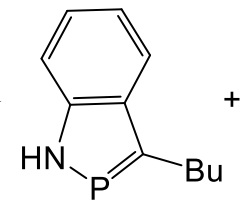

98<smiles>CC(C)c1[nH]c2ccccc2p1</smiles>

99

\section{Scheme 28}

\subsection{Reaction of chlorophosphenium triflate with potassium metal}

Treatment of chlorophosphenium triflate $\mathbf{1 0 0}$ with potassium metal in toluene at $25{ }^{\circ} \mathrm{C}$ resulted in a pale yellow crystalline 1,2-azaphospholidine 104 (Scheme 29). It was assumed that the two-electron reduction of the idealized chlorophosphenium ion $\mathbf{1 0 0}$ proceeded in two steps; addition of the first electron would generate the monoradical 101. Addition of the second electron would then generate the triplet diradical phosphinidene 102. The conversion of $\mathbf{1 0 2}$ to 103 took place by an intramolecular P-C bond formation to afford the derivative 103. Finally, the latter 103 underwent $\mathrm{N}-\mathrm{C}$ bond cleavage and hydrogen transferred from 
$\beta$-methyl group to the nascent imido nitrogen center forming the isolated 1,2-azaphospholidine isomer 104 (Scheme 29). ${ }^{63}$
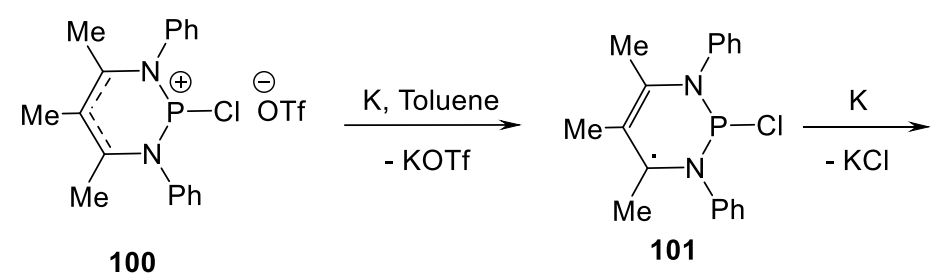

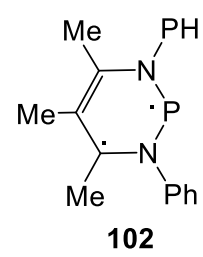
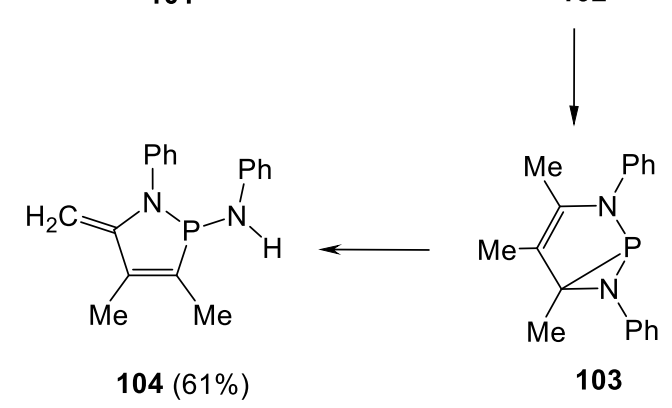

\section{Scheme 29}

\section{Synthetic Methods for Functionalized 1,2-Azaphosphorine Derivatives}

\subsection{Cyclization of phosphinamides using various bases}

Cyclization of different phosphinamides 105 using various bases at the boiling point of the used solvent furnished 2-oxido-1,2-azaphosphinanes 106 in different yields through removal of ethanol or hydrogen halide (Scheme 30). ${ }^{64,65}$

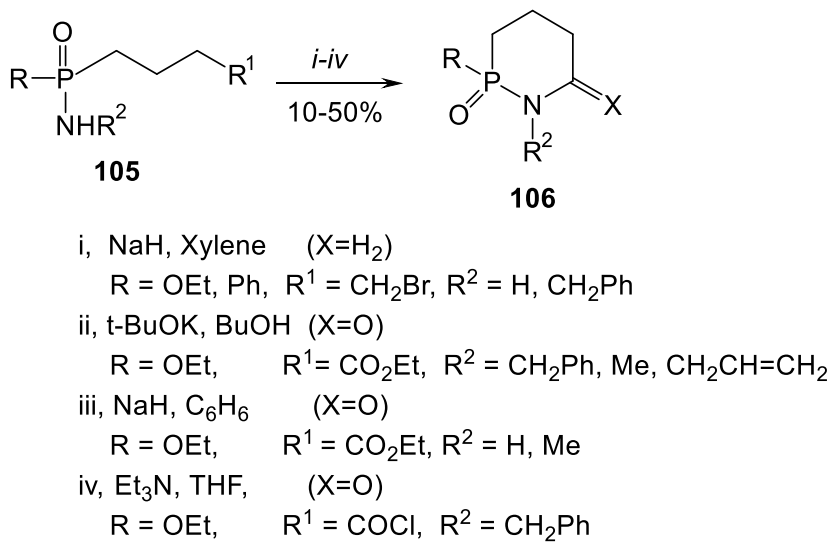

\section{Scheme 30}

\subsection{Cyclization of $\boldsymbol{N}$-[2-ethyl-3-methylhexa-1,3-dien-1-yl]butan-1-imine with $\mathrm{RPCl}_{2}$}

Cyclocondensation of $\mathrm{N}$-[2-ethyl-3-methylhexa-1,3-dien-1-yl]butan-1-imine (107) with dichlorophosphine derivatives in dry benzene at $50{ }^{\circ} \mathrm{C}$ containing $\mathrm{Et}_{3} \mathrm{~N}$ afforded 1-butyl-3,5-diethyl-1,2-dihydro-1,2-azaphosphorines (108) (Scheme 31). ${ }^{66}$ 


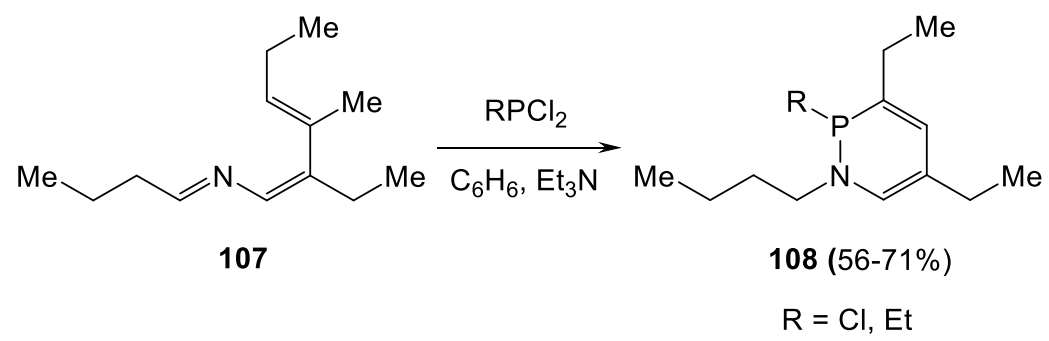

\section{Scheme 31}

\subsection{Cyclization of 2-aminobiphenyl with $\mathrm{PCl}_{3}$}

Reaction of 2-aminobiphenyl (109) with phosphorus trichloride in boiling benzene at $65{ }^{\circ} \mathrm{C}$ containing a catalytic amount of $\mathrm{AlCl}_{3}$ afforded 10-chloro-9,10-dihydro-9,10-azaphosphaphenanthrene (110). Compound $\mathbf{1 1 0}$ has an active chlorine atom which can be substituted by a wide range of nucleophiles. Thus, treatment of the product $\mathbf{1 1 0}$ with methyl magnesium iodide in $\mathrm{CH}_{2} \mathrm{Cl}_{2}$ gave 10-methyl-9,10-dihydro-9,10azaphosphaphenanthrene 10-methiodide (111) while its reaction with aryl magnesium bromide in $\mathrm{dry} \mathrm{CH}_{2} \mathrm{Cl}_{2}$ at room temperature formed 10-aryl-9,10-dihydro-9,10-azaphosphaphenanthrenes 112 (Scheme 32). Also, reaction of compound $\mathbf{1 1 0}$ with (2-methoxyphenyl) magnesium bromide in THF at $60{ }^{\circ} \mathrm{C}$ gave 10 -(2-methoxyphenyl)-9,10-dihydro-9,10-azaphosphaphenanthrene (113) which was phosphorylated with chlorodiarylphosphine in acetonitrile at room temperature to give 5-(diarylphosphanyl)-6-(2-methoxyphenyl)-5,6-dihydrodibenzo[c,e][1,2]azaphosphinines 114 and 115 (Scheme 32). ${ }^{67-69}$
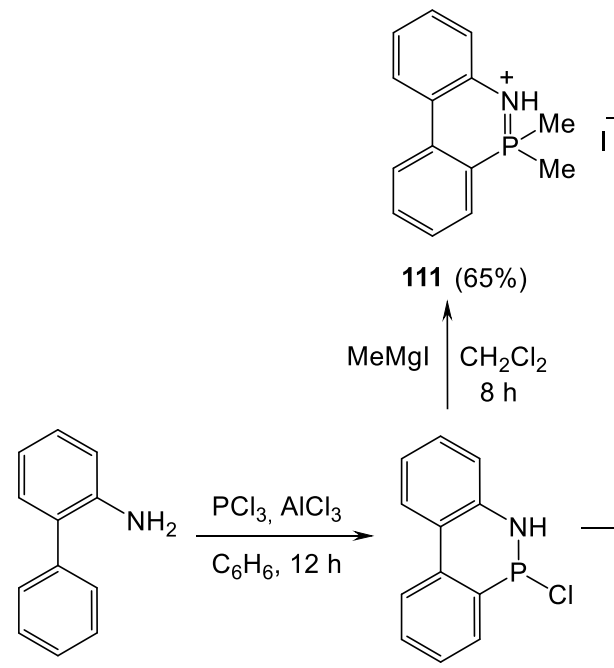

109

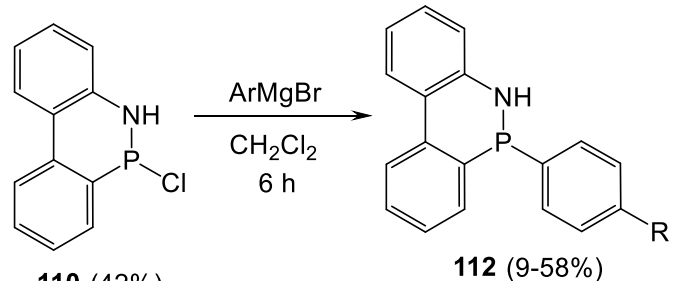

$$
\begin{aligned}
& 110(42 \%) \\
& \text { THF } \downarrow 2\left(2-\mathrm{MeOC}_{6} \mathrm{H}_{4}\right) \mathrm{MgBr}
\end{aligned}
$$

$\mathrm{R}=\mathrm{H}, \mathrm{Br}, \mathrm{Me}, \mathrm{NMe}_{2}$
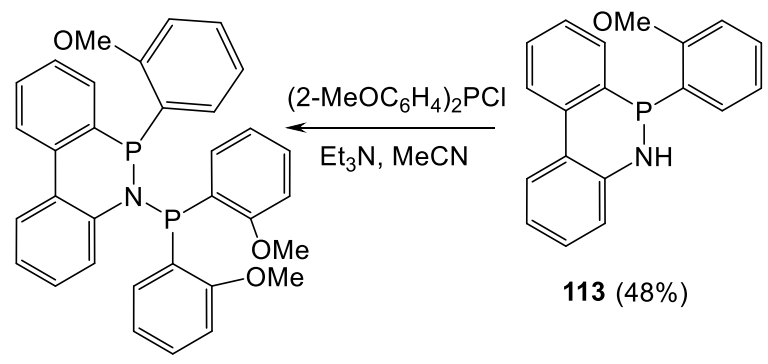

$\underset{\mathrm{Et}_{3} \mathrm{~N}, \mathrm{MeCN}}{\stackrel{(\mathrm{Ph})_{2} \mathrm{PCl}}{\longrightarrow}}$<smiles>COc1ccccc1P1c2ccccc2-c2ccccc2N1P(c1ccccc1)c1ccccc1</smiles>

$114(57 \%)$ 
Compound $112(\mathrm{R}=\mathrm{H})$ acts as a substrate for the preparation of a series of functionalized 1,2-azaphosphaphenanthrenes. Thus, its reaction with bromobenzene in the presence of anhydrous $\mathrm{AlCl}_{3}$ in current of nitrogen gas furnished 10-pheny1-9,10-dihydro-9,10-azaphosphaphenanthrene 10-oxide (116) (Scheme 33). Moreover, its reaction with methyl iodide in dry benzene gave 10-phenoxy-9,10-dihydro-9,10-azaphosphaphenanthrene methiodide 117 (Scheme 33). Oxidation of compound $\mathbf{1 1 2}$ by hydrogen peroxide in ethanol at room temperature afforded the corresponding oxide 118. Furthermore, reaction of compound 112 with chlorodiphenylphosphine or bis(2-methoxyphenyl)chlorophosphine in acetonitrile in the presence of triethylamine gave 5-(diarylphosphanyl)-6-phenyl-5,6-dihydrodibenzo[c,e][1,2]azaphosphinines (119) (Scheme 33). ${ }^{67-69}$
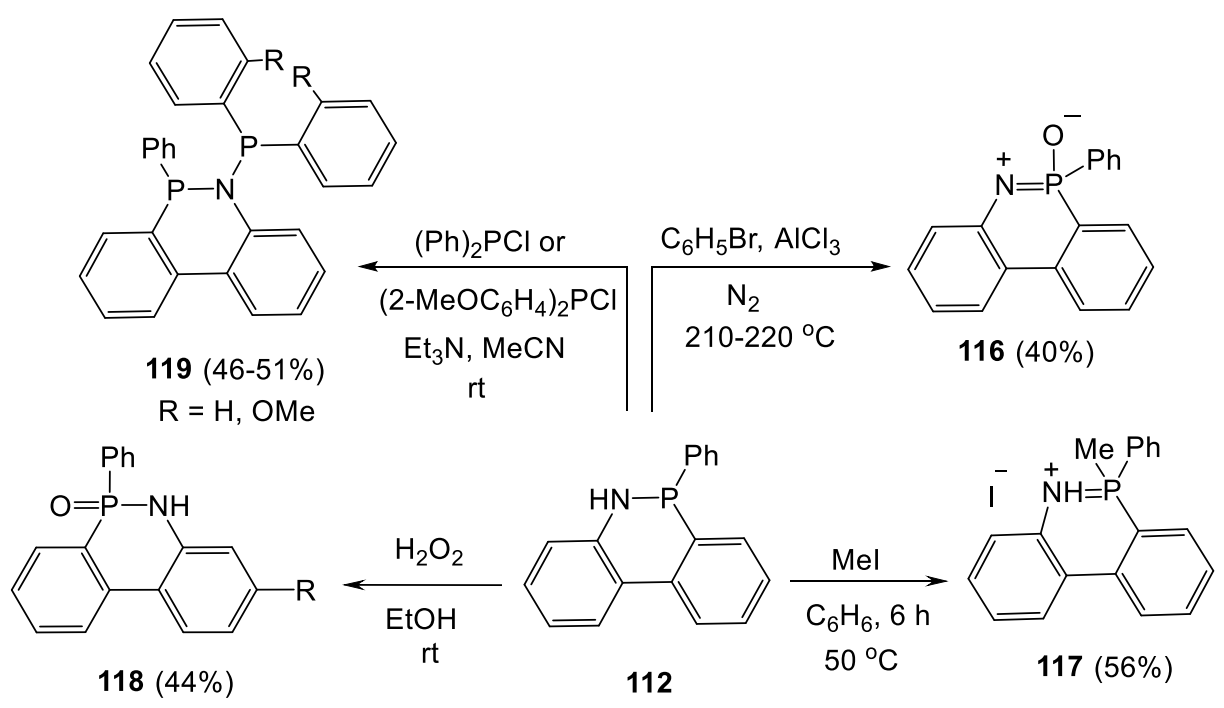

\section{Scheme 33}

\subsection{Cyclization of naphthylethylamine with thiophosphoryl chloride}

Treatment of naphthylethylamine $\mathbf{1 2 0}$ with thiophosphoryl chloride in dry pyridine at $100{ }^{\circ} \mathrm{C}$ gave 2-[(naphthalene-1-yl)ethyl]phosphoramidothioic dichloride (121), which with $\mathrm{AlCl}_{3}$ at $165{ }^{\circ} \mathrm{C}$ for $8 \mathrm{~h}$ gave 4-chloro-1,2,3,4-tetrahydronaphtho[2,1-c][1,2]azaphosphinine 4-sulfide (122) (Scheme 34). ${ }^{70}$

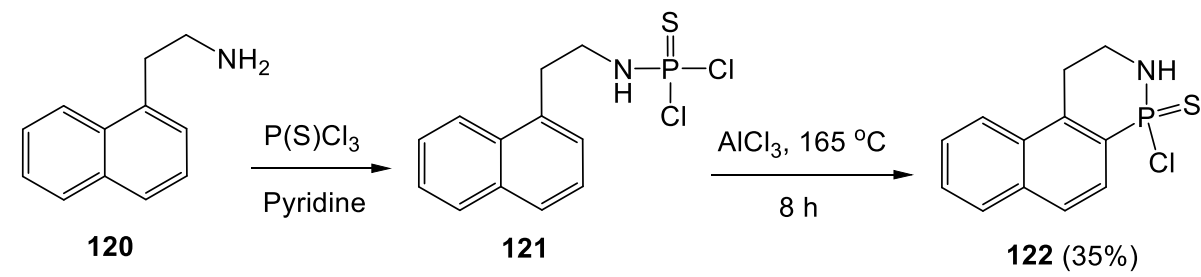

Scheme 34

\subsection{Cyclization of 2-amino-3-ethynylnaphthalenes with triphenoxyphosphine}

Cyclization of 2-amino-3-ethynylnaphthalenes (123) with triphenoxyphosphine in dry pyridine for $12 \mathrm{~h}$ furnished naphtho[2,3-e][1,2]azaphosphorines (124) in moderate yields (Scheme 35). ${ }^{71}$ 


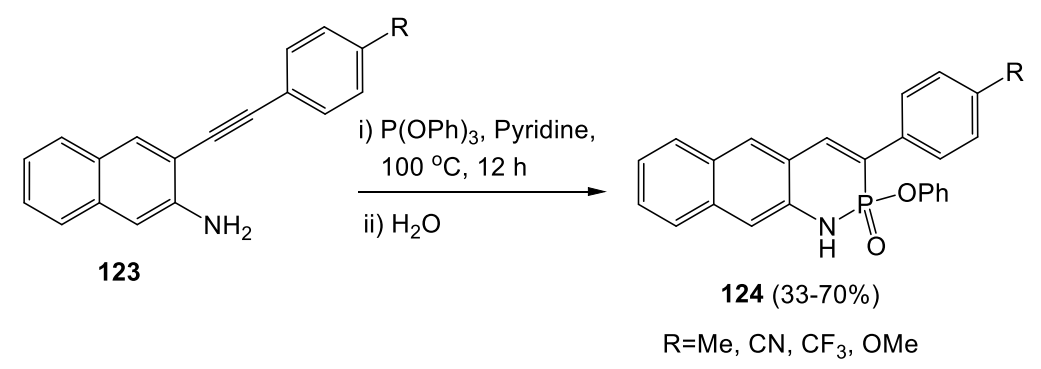

\section{Scheme 35}

\subsection{Cyclization of 2-(1H-indol-3-yl)- $\mathrm{N}$-phenethylacetamides with phosphorus oxychloride}

2-(1H-indol-3-yl)- $N$-phenethylacetamides (125) underwent double condensation using excess of phosphorus oxychloride at $175{ }^{\circ} \mathrm{C}$ to form the phosphoramide derivatives 127 (Scheme 36). Compounds 127 underwent another cyclocondensation reaction through the $\alpha$-position of the indole nucleus followed by treatment with ethanol at room temperature to yield 8-ethoxy-5,6-dihydro-2,3-disubstituted-9H-indolo[2,3-c]isoquino[1,2-f] $[1,2]$ azaphosphorine 8-oxides 128 (Scheme 36). ${ }^{72,73}$
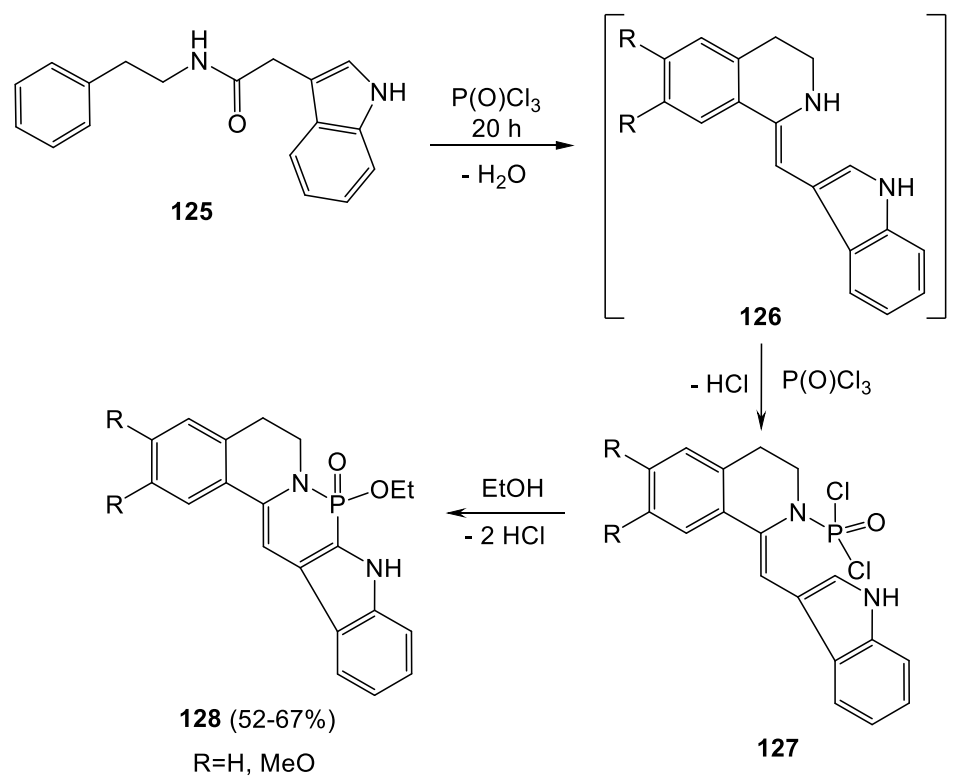

\section{Scheme 36}

\subsection{Reaction of a $1 \lambda^{5}, 3 \lambda^{5}$-diphosphete adduct with ethyl isothiocyanate}

Reaction of 1,2-dihydro- $1 \lambda^{5}, 3 \lambda^{5}$-diphosphete-2-carbothioamide adduct 129 with ethyl isothiocyanate gave the 1,2,4-azadiphosphinine intermediate 130, which reacted with a second molecule of ethyl isothiocyanate to give the acyclic ketenimine 131 (Scheme 37). This easily underwent cyclization to afford the isolated 1,2-azaphosphinine 132 (Scheme 37). ${ }^{74}$ 


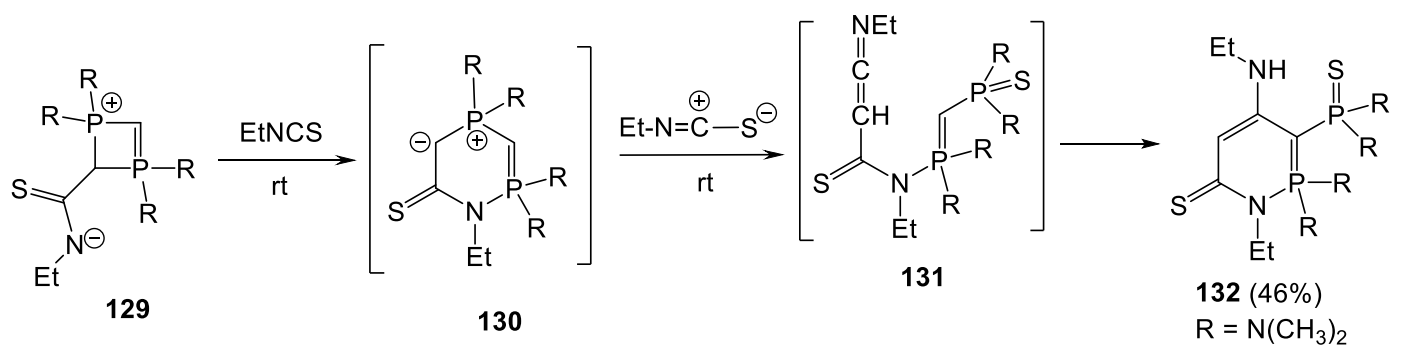

\section{Scheme 37}

\subsection{Ring expansion of 2,3-dihydro-1,2-azaphospholes by dichlorocarbene}

Reaction of 2,3-dihydro- $1 \mathrm{H}$-1,2-azaphosphole oxides (133) with dichlorocarbene at $-25{ }^{\circ} \mathrm{C}$ gave the corresponding 1,2-azaphosphinine oxides 134 through Ciamician-Dennsted rearrangement (Scheme 38). ${ }^{75}$

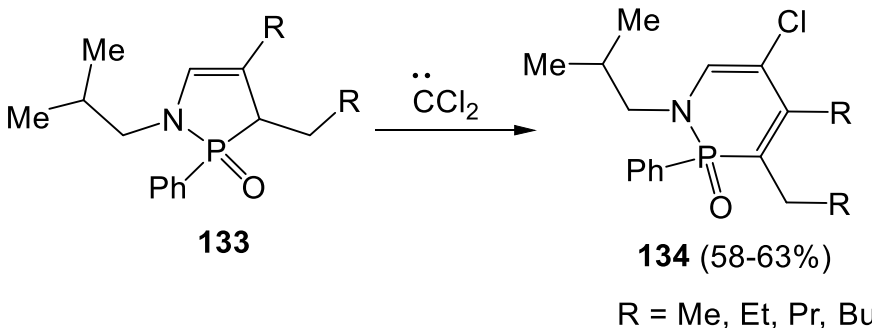

\section{Scheme 38}

\subsection{Reaction of 1,3,2-diazaphosphinines with alkynes}

Reaction of 4,6-di-t-butyl-1,3,2-diazaphosphinine (135) with different alkynes in toluene $100{ }^{\circ} \mathrm{C}$ afforded the corresponding substituted 1,2-azaphosphinines 136 through [4+2] cycloaddition, while its reaction with bis-alkynes furnished the 1,2-azaphosphinine-based bidentate ligands 137 (Scheme 39). ${ }^{76,77}$
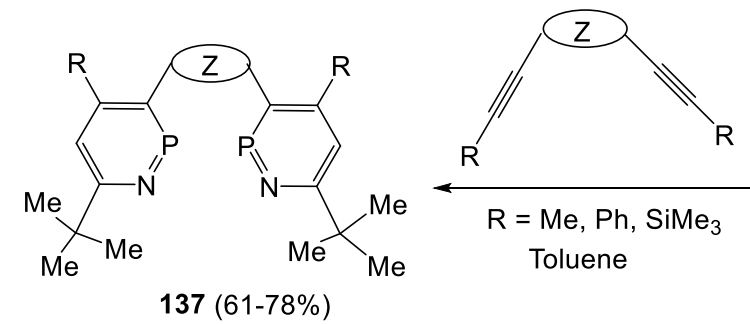

$\mathrm{Z}=\mathrm{SiMe}_{2}, \searrow_{\mathrm{PPh}},\left(\mathrm{CH}_{2}\right)_{3}$<smiles>C[SiH](C)c1pc(-c2ccccc2)c(-c2ccccc2)cc1-c1ccccc1</smiles>

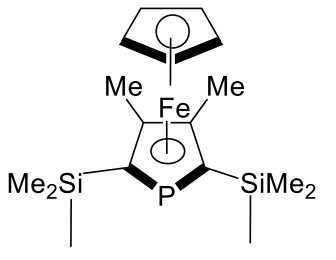

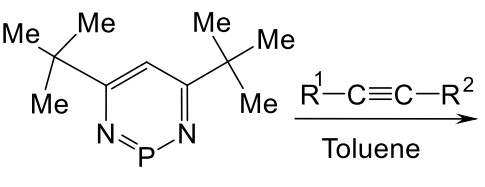

135

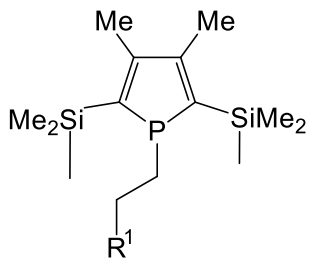

$\mathrm{R}^{1}=\mathrm{Cl}, \mathrm{CN}, \mathrm{CO}_{2} \mathrm{Et}$

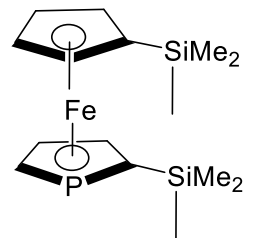

Scheme 39 


\section{Synthetic Methods for Functionalized 1,2-Azaphosphepine Derivatives}

\subsection{Ring expansion of phospholenes with benzonitrile}

Treatment of 1-oxo-3,4-dimethyl-3-phospholenes (138) with $n$-BuLi in benzonitrile at $-70{ }^{\circ} \mathrm{C}$ followed by hydrolysis formed the corresponding 1,2-azaphosphepine oxides 139 (Scheme 40). ${ }^{78}$

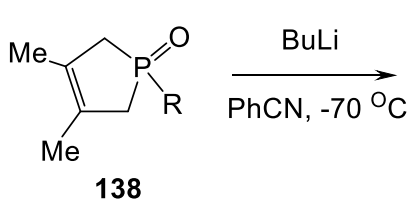

138

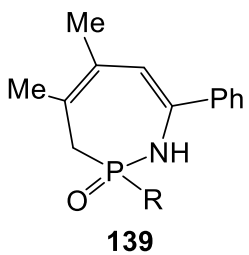

$\mathrm{R}=\mathrm{EtO}(27 \%)$

$\mathrm{R}=\mathrm{Ph} \quad(42 \%)$

\section{Scheme 40}

\subsection{Ring expansion of 1,2-azaphosphinines with dichlorocarbene}

Reaction of 1-t-butyl-2-phenyl-3,5-dipropyl-1H-1,2-azaphosphinine (140) with dichlorocarbene by regioselective addition to the $\mathrm{C}_{5}-\mathrm{C}_{6}$ double bond at $-25{ }^{\circ} \mathrm{C}$ yielded the 3-oxo-2-aza-3-phosphabicycloheptene 141 (Scheme 41). Flash vacuum thermolysis of 141 gave 6-chloro-3,4-dipropyl-2-phenyl-2-oxo-2H-1,2azaphosphepine (142) and substituted 3-chloropyridines 143 (Scheme 41). ${ }^{79}$
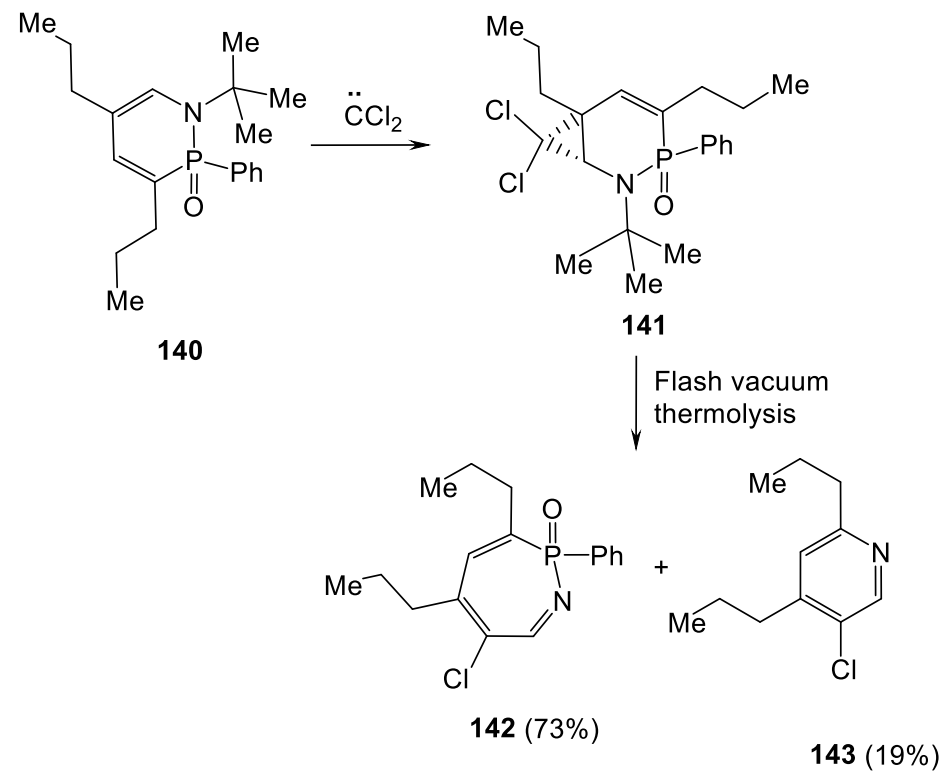

\section{Scheme 41}

\section{Conclusions}

In conclusion, this survey has presented the synthetic methods for 1,2-azaphospholes, 1,2-azaphosphorines and 1,2-azaphosphepines. Most of these synthetic methods require special reaction conditions and specific starting materials that are not available in some laboratories. However, cyclization of amino- and hydrazino compounds with phosphorus reagents or cyclization of aminophosphorus compounds with simple 
electrophiles are convenient and easy to perform. We hope that this review may encourage scientists to create new routes towards these ring systems with important biological activity.

\section{Acknowledgements}

The authors extend their appreciation to the Deanship of Scientific Research at King Khalid University for funding this work through General Research Project under grant number G.R.P./15/41.

\section{References}

1. Bansal, R. K. Topics in Heterocyclic Chemistry: Phosphorus Heterocycles II, 2010. http://doi.org/10.1007/978-3-642-12254-5

2. Mulzer, J. Angew. Chem. Int. Ed. 2001, 40, 4293. http://doi.org/10.1002/1521-3773(20011119)40:22<4293::AID-ANIE4293>3.0.CO;2-1

3. Kafarski, P.; Lejczak, B. Curr. Med. Chem. 2001, 1, 301. https://doi.org/10.2174/1568011013354543

4. Mader, M. M.; Bartlett, P. A. Chem. Rev. 1997, 97, 1281. https://doi.org/10.1021/cr960435y

5. Kafarski, P., Lejczak, B. Phosphorus Sulfur Silicon Relat. Elem. 1991, 63, 193. https://doi.org/10.1080/10426509108029443

6. Mukherjee, S.; Huang, M.-C.; Guerra, F.; Wang, K.; Oldfield, E. J. Am. Chem. Soc. 2009, 131, 8374. https://doi.org/10.1021/ja902895p

7. Moonen, K.; Laureyn, I.; Stevens, C. V. Chem. Rev. 2004, 104, 6177. https://doi.org/10.1021/cr030451c

8. Turcheniuk, K. V.; Shevchenko, I. V. Phosphorus, Sulfur Silicon Relat. Elem. 2011, 186, 766. https://doi.org/10.1080/10426507.2010.507732

9. Chen, X.-D.; Alidori, S.; Puschmann, F. F.; Santiso-Quinones, G.; Benko, Z.; Li, Z.; Becker, G.; Gruetzmacher, H. F.; Gruetzmacher, H. Angew. Chem. Int. Ed. 2014, 53, 1641.

https://doi.org/10.1002/anie.201308220

10. Franz, J. E.; Mao, M. K.; Sikorski, J. A. Gliphosate: a unique global herbicide. American Chemical Society: Washington, DC, 1997.

11. Tajti, A.; Keglevich, G. Organophosphorus Chemistry: Novel Developments 2018, 53-65. https://doi.org/10.1515/9783110535839

12. Keglevich, G. Curr. Org. Chem. 2019, 23, 1342. https://doi.org/10.2174/1385272823666190726093322

13. Pudovik, A. N. Chemistry of organophosphorus compounds. MIR: Moskow, 1989.

14. Mian, M. R.; Islamoglu, T.; Afrin, U.; Goswami, S.; Cao, R.; Kirlikovali, K. O.; Hall, M. G.; Peterson, G. W.; Farha, O. K. Chem. Mater. 2020, 32, 6998. http://doi.org/10.1021/acs.chemmater.0c02373

15. Bricklebank, N. Organophosphorus Chem. 2003, 33. 289. https://doi.org/10.1039/9781847554529-00289

16. Mathey, F. Phosphorus-carbon heterocyclic chemistry: the rise of a new domain. Pergamon: New York, 2001. 
17. Quin, L. D. The heterocyclic chemistry of phosphorus: systems based on the phosphorus-carbon bond. Wiley: New York, 1981.

18. Golla, M.; Devineni, S. R.; Syed, R.; Rayalacheru, B. K.; Maram, R.; Chamarthi, N. R. Phosphorus, Sulfur Silicon Relat. Elem. 2017, 192, 794.

https://doi.org/10.1080/10426507.2016.1277528

19. Darrow, J. W.; Drueckenhammer, D. G. J. Org. Chem. 1994, 59, 2976.

https://doi.org/10.1021/jo00090a014

20. Abdou, W. M.; Barghash, R. F.; Khidre, R. E. Monatsh Chem. 2013, 144, 1233.

https://doi.org/10.1007/s00706-013-0950-6

21. Yamada, M.; Asai, K.; Yamashita, J.; Suyama, T.; Niimi, T.; Maddali, K.; Fujie, M.; Nakamura, S.; Yamashita, M. Phosphorus, Sulfur Silicon Relat. Elem. 2010, 185, 2286.

https://doi.org/10.1080/10426501003598622

22. Andujar, C. M.; Perez A. I.; Lopez O. F. Tetrahedron 2002, 58, 2569.

https://doi.org/10.1016/S0040-4020(02)00144-8

23. Gilard, V.; Martino, R.; Malet-Martino, M.; Niemeyer, U.; Pohl, J. J. Med. Chem. 1999, 42, 2542. https://doi.org/10.1021/jm980587g

24. Smith, B. R.; Eastman, C. M.; Njardarson, J. T. J. Med. Chem. 2014, 57, 9764.

https://doi.org/10.1021/im501105n

25. Lowe, P.; Feldt, M.; Wuensche, M. A.; Wilm, L. F. B.; Dielmann, F. J. Am. Chem. Soc. 2020, $142,9818$. https://doi.org/10.1021/jacs.0c03494

26. Ali, T. E.; Halachevea, S. S. Heteroat. Chem. 2009, 20, 117.

https://doi.org/10.1002/hc.20520

27. Latypov, S. K.; Ganushevich, Y. S.; Kondrashova, S. A.; Kharlamov, S. V.; Milyukov, V. A.; Sinyashin, O. G. Organometallics 2018, 37, 2348.

https://doi.org/10.1021/acs.organomet.8b00319

28. Ali, T. E. Eur. J. Med. Chem. 2009, 44, 4539. https://doi.org/10.1016/i.ejmech.2009.06.022

29. Abdel-Kariem, S. M.; Ali, T. E. J. Heterocycl. Chem. 2017, 54, 2916.

https://doi.org/10.1002/jhet.2902

30. Hansmann, M. M.; Ruiz, D. A.; Liu, L.; Jazzar, R.; Bertrand, G. Chem. Sci. 2017, 8, 3720. https://doi.org/10.1039/C7SC00300E

31. Sevcik, R.; Prihoda, J.; Necas, M. Polyhedron 2017, 124, 96.

https://doi.org/10.1016/j.poly.2016.12.036

32. Ali, T. E.; Ibrahim, M. A.; El-Edfawy, S. M. Phosphorus, Sulfur Silicon Relat. Elem. 2017, 192, 819.

https://doi.org/10.1080/10426507.2017.1287183

33. Streubel, R.; Wilkens, H.; Rohde, U.; Ostrowski, A.; Jeske, J.; Ruthe, F.; Jones, P. G. Eur. J. Inorg. Chem. 1999, 1567.

https://doi.org/10.1002/ejic.201801135

34. Sharma, B.; Umadevi, D.; Narahari, S. G. Phys. Chem. Chem. Phys. 2012, 14, 13922.

https://doi.org/10.1039/C2CP41834G

35. Manthey, M. K.; Huang, D. T. C.; Bubb, W. A.; Christopherson, R. I. J. Med. Chem. 1998, 41, 4550. https://doi.org/10.1021/im970814z

36. Collins, D. J.; Hetherington, J. W.; Swan, J. M. Aust. J. Chem. 1974, 27, 1759. 
https://doi.org/10.1071/CH9741759

37. Natchev, I. A. Bull. Chem. Soc. Jpn. 1988, 61, 3699.

https://doi.org/10.1246/bcsj.61.3699

38. Schmidpeter, A.; Zeiss, W. Angew. Chem. Int. Ed. 1971, 10, 396.

https://doi.org/10.1002/anie.197103961

39. Schmidpeter, A. Two Adjacent Heteroatoms with at least One Phosphorus, Arsenic, or Antimony. Comprehensive Heterocyclic Chemistry, 1996, 709-714.

https://doi.org/10.1016/B978-008096518-5.00073-3

40. Ali, T. E.; Assiri, M. A.; El-Shaaer, H. M.; Fouda, A. M.; Hassan, M. M.; Hassanin, N. M. Heterocycles 2019, $98,681$.

https://doi.org/10.3987/COM-19-14062

41. Ali, T. E.; Assiri, M. A.; El-Shaaer, H. M.; Hassan, M. M.; Fouda, A. M.; Hassanin, N. M. Synth. Commun. 2019, 49, 2983.

https://doi.org/10.1080/00397911.2019.1652323

42. Ali, T. E.; Hassan, M. M. Res. Chem. Intermed. 2018, 44, 173.

https://doi.org/10.1007/s11164-017-3096-z

43. Yavari, I.; Alizadeh, A.; Anary-Abbasinejad, M. Mol. Diversity 2005, 9, 241.

https://doi.org/10.1007/s11030-005-3051-6

44. Ruiz-Gomez, G.; Iglesias, M. J.; Serrano-Ruiz, M.; Lopez-Ortiz, F. J. Org. Chem. 2007, 72, 9704. https://doi.org/10.1021/jo701607s

45. Ruiz-Gomez, G.; Francesch, A.; Cuevas, C.; Serrano-Ruiz, M.; Iglesias, M. J.; Lopez-Ortiz, F. Tetrahedron 2012, 68, 995.

https://doi.org/10.1016/j.tet.2011.11.094

46. Liu, L. L.; Stephana, D. W. Chem. Commun. 2018, 54, 1041.

https://doi.org/10.1039/C7CC09090K

47. Wang, C.; Mu, W.-H.; Fang, D.-C. Acta Chim. Sinica 2006, 64, 1665.

48. Wilkens, H.; Ruthe, F.; Jones, P. G.; Streubel, R. Chem. Commun. 1998, 1529.

https://doi.org/10.1039/A802569J

49. Wilkens, H.; Ostrowski, A.; Jeske, J.; Ruthe, F.; Jones, P. G.; Streubel, R. Organometallics 1999, $18,5627$. https://doi.org/10.1021/om990537p

50. Streubel, R.; Hoffmann, N.; Schiebel, H. M.; Ruthe, F.; Jones, P. G. Eur. J. Inorg. Chem. 2002, 957. https://doi.org/10.1002/1099-0682(200203)2002:4<957::AID-EJIC957>3.0.CO;2-2

51. Streubel, R.; Wilkens, H.; Ostrowski, A.; Neumann, C.; Ruthe, F.; Jones, P. G. Angew. Chem. Int. Ed. 1997, 36, 1492.

https://doi.org/10.1002/anie.199714921.

52. Streubel R.; Wilkens, H.; Jones, P. G. Chem. Commun. 1999, 2127.

https://doi.org/10.1039/a905752h

53. Streubel, R.; Wilkens, H.; Ruthe, F.; Jones, P. G. Tetrahedron 2000, 56, 21.

https://doi.org/10.1016/S0040-4020(99)00768-1

54. Streubel, R.; Hoffmann, N.; Ruthe, F.; Jones, P. G. Polyhedron 2002, 21, 119. https://doi.org/10.1016/S0277-5387(01)00976-7

55. Hoffmann, N.; Wismach, C.; Ernst, L.; Schiebel, H. M.; Jones, P. G.; Streubel, R. Eur. J. Inorg. Chem. 2003, 1815. 
https://doi.org/10.1002/ejic.200200649

56. Helten, H.; Frantzius, G.; Schnakenburg, G.; Daniels, J.; Streubel, R. Eur. J. Inorg. Chem. $2009,2062$. https://doi.org/10.1002/ejic.200900190

57. Harger, M. J. P. J. Chem. Soc. Perkin Trans. 1 1974, 22, 2604.

https://doi.org/10.1039/p19740002604

58. Peters, C.; Tabellion, F.; Schröder, M.; Bergsträber, U.; Preuss, F.; Regitz, M. Synthesis $2000,417$. https://doi.org/10.1055/s-2000-6353

59. Streubel, R.; Schiemann, U.; Jones, P. G.; Huy, N. H. T.; Mathey, F. Angew. Chem. Int. Ed. 2000, $39,3686$. https://doi.org/10.1002/1521-3773(20001016)39:20<3686::AID-ANIE3686>3.0.CO;2-I

60. Streubel, R.; Schiemann, U.; Huy, N. H. T.; Mathey, F. Eur. J. Inorg. Chem. 2001, 3175. https://doi.org/10.1002/1099-0682(200112)2001:12<3175::aid-ejic3175>3.0.co;2-c

61. Streubel, R.; Hoffmann, N.; Frantzius, G.; Wismach, C.; Jones, P. G.; Schiebel, H.; Grunenberg, J.; Vong, H.; Chaigne, P.; Compain, C.; Huy, N. H. T.; Mathey. F. Organometallics 2003, 22, 5427. https://doi.org/10.1021/om030547x

62. Karaghiosoff, K.; Klehr, H.; Schmidpeter, A. Chem. Ber. 1986, 119, 410. https://doi.org/10.1002/cber.19861190204

63. Lu, Z.; Findlater, M.; Cowley, A. H. Chem. Commun. 2007, 27, 2873. https://doi.org/10.1039/b704266c

64. Hewitt, D. G.; Newland, G. L. Aust. J. Chem. 1977, 30, 579. https://doi.org/10.1071/ch9770579

65. Hewitt, D. G.; Teese, M. W. Aust. J. Chem. 1984, 37, 1631. https://doi.org/10.1071/ch9841631

66. Kibardin, A. M.; Mikhailov, V. B.; Levina, E. Ya.; Mikhailov, Yu. B.; Pudovik, A. N. USSR Patent 1410490 A1 19890930, 1989.

67. Dewar, M. J. S.; Kubba, V. P. J. Am. Chem. Soc. 1960, 82, 5685.

https://doi.org/10.1021/ja01506a032

68. Campbell, I. G. M.; Way, J. K. J. Chem. Soc. 1960, 5034.

https://doi.org/10.1039/jr9600005034

69. Nifantev, I. E.; Vinogradov, A. A.; Vinogradov, A. A.; Roznyatovsky, V. A.; Grishin, Y. K.; Ivanyuk, A. V.; Sedov, I. V.; Churakov, A. V.; Ivchenko, P. V. Organometallics 2018, 37, 2660.

https://doi.org/10.1021/acs.organomet.8b00427

70. Grewal, G. S.; Jindal, R. T.; Bhatia, M. S. Indian J. Chem. 1980, $19 B, 404$.

71. Takaesu, N. A.; Ohta, E.; Zakharov, L. N.; Johnson, D. W.; Haley, M. M. Organometallics 2017, $36,2491$. https://doi.org/10.1021/acs.organomet.7b00281

72. Morrison, G. C.; Waite, R. O.; Shovel, J. J. Heterocycl. Chem. 1966, 3, 540. https://doi.org/10.1002/jhet.5570030435

73. Shavel, J. J.; Morrison, G. C. US Patent 3452024 A 19690624, 1969.

74. Fluck, E. Heteroat. Chem. 1995, 6, 355. https://doi.org/10.1002/hc.520060413

75. Tan, W. H. L. W.; Foucaud, A. J. Chem. Res. Synop. 1991, 2, 52.

76. Welfele, S.; Mezailles, N.; Maigrot, N.; Ricard, L.; Mathey, F.; Le Floch, P. New J. Chem. 2001, $25,1264$. https://doi.org/10.1039/b103779j

77. Bansal, R. K.; Kumawat, S. K. Tetrahedron 2008, 64, 10945. 
https://doi.org/10.1016/i.tet.2008.09.037

78. Mathey, F.; Lampin, J. P. Tetrahedron Lett. 1972, 19, 1949.

https://doi.org/10.1016/S0040-4039(01)84759-6

79. Tan, W. W.; Bourdieu, C.; Foucaud, A.; Bedel, C. Bull. Soc. Chim. Fr. 1993, 130, 96.

\section{Authors' Biographies}

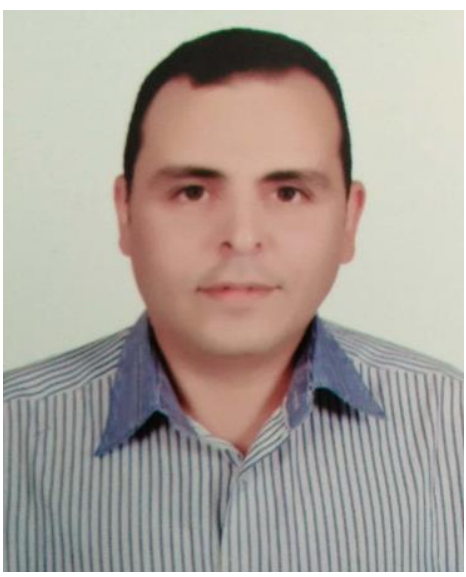

Tarik E. Ali was born in Cairo, Egypt, in 1975. He is presently full professor of Organic Chemistry, Department of Chemistry, Faculty of Education, Ain Shams University, Cairo, Egypt. Currently, he works at Department of Chemistry, Faculty of Science, King Khalid University, Abha, Saudi Arabia. He graduated with BSc (Physics and Chemistry) from Ain Shams University in 1997. He received his MSc and PhD degrees in 2001 and 2005, respectively, in Heterocyclic Chemistry from Ain Shams University. Awarded a post-doctoral scientific grant for supporting young researchers (2007) from the Ministry of Higher Education and Scientific Research (Egypt) in organophosphorus laboratory, Institute of Polymers, Bulgarian Academy of Science, Sofia, Bulgaria. His CV was mentioned in Who's Who in the World in 2011, 2012, 2013, 2015, 2016, 2018 and 2020. He has published more than 80 scientific papers including 15 review articles, all in international journals. His research interests are in synthesis and chemical reactivity of phosphorus compounds containing bioactive heterocyclic systems.

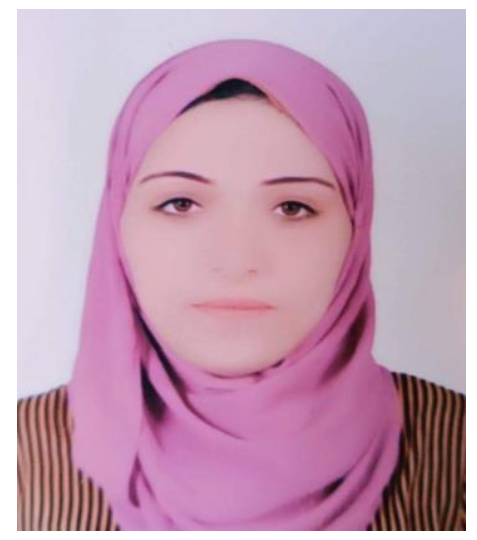

Noha M. Hassanin was born in 1991 in Kaluobia, Egypt. In 2013, she graduated from Ain Shams University, Faculty of Education, Department of Chemistry. She obtained her MSc Degree in Organophosphorus Chemistry in 2018. She has published about 8 scientific papers in international journals. She is still working on her PhD thesis which includes design and synthesis of biologically active organophosphorus compounds. 


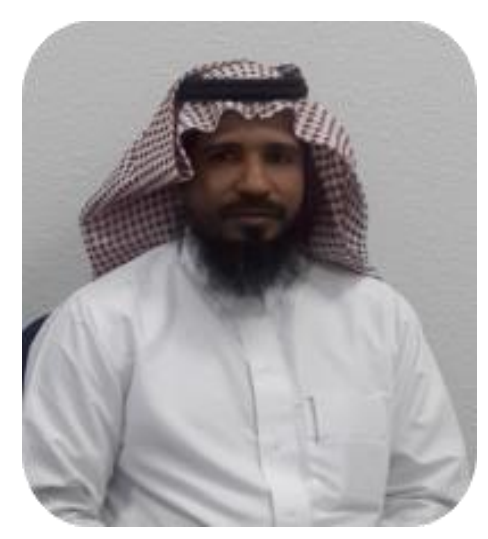

Mohammed A. Assiri is presently assistant professor at Department of Chemistry, Faculty of Science, King Khalid University, Abha, Saudi Arabia. He graduated with BSc (Chemistry) from Department of Chemistry, Faculty of Science, King Khalid University, Abha, Saudi Arabia in 2004. Also, he received his MSc and PhD degrees in 2014 and 2016, respectively, in organic and green Chemistry from University of Wyoming, Laramie, WY, USA. His research interests are in activities related to organic chemistry, green chemistry, and chemical engineering.

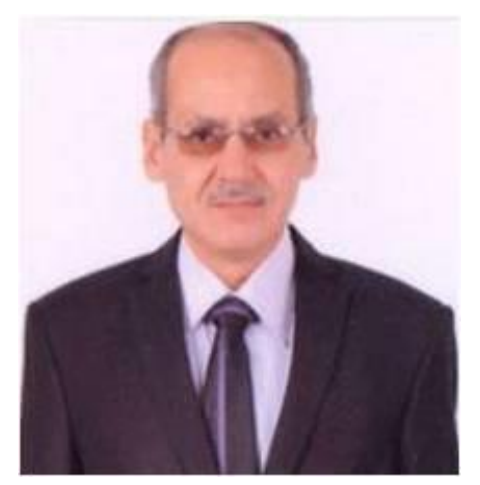

Hafez M. Elshaaer was born in Cairo, Egypt, in 1959. He is presently full professor of Organic Chemistry, Department of Chemistry, Faculty of Education, Ain Shams University, Cairo, Egypt. He graduated with BSc and MSc from Ain Shams University. He received his PhD degree in Heterocyclic Chemistry from Department of Organic Chemistry, Faculty of Natural Sciences, Comenius University, Bratislava, Slovakia. He has published 35 scientific papers in international journals. His research interests are in synthesis and chemical reactivity of pyran and chromone systems.

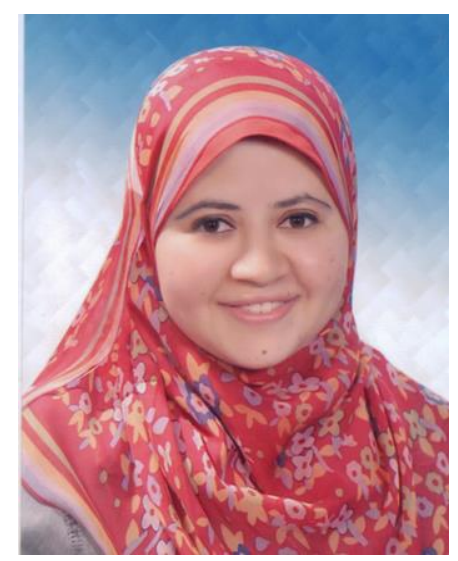

Somaia M. Abdel-Karim was born in 1985 in Cairo, Egypt. She is presently associate professor at Ain Shams 
University, Faculty of Education, Department of Chemistry. In 2006 she graduated from Ain Shams University, Faculty of Education, Department of Chemistry. Also, she received her M.Sc. and Ph.D. degrees in 2011 and 2014, respectively, in Organophosphorus Chemistry. She has published about 15 scientific papers in international journals. Her research interests are in synthesis and chemical reactivity of phosphorus compounds containing bioactive heterocyclic systems.

This paper is an open access article distributed under the terms of the Creative Commons Attribution (CC BY) license (http://creativecommons.org/licenses/by/4.0/ 